\title{
MASTER
}

DOE/NASA CONTRACTOR REPORT

DOE /NASA CR- 150560

\section{SOLAR HEAT TRANSPORT FLUIDS FOR SOLAR ENERGY COLLECTION SYSTEMS (A Collection of Quarterly Reports)}

Prepared from documents furnished by

Houston Chemical Company

Division of PPG Industries, Inc.

1 Gateway Center

Pittsburg, PA 15222

Under Contract NAS8-32255 with

National Aeronautics and Space Administration

George C. Marshall Space Flight Center, Alabama 35812

For the U. S. Department of Energy

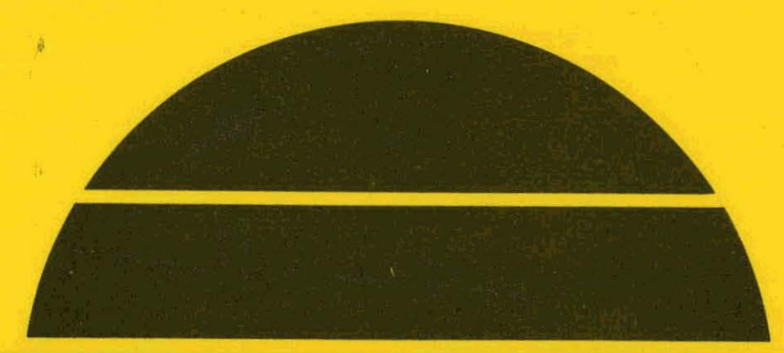

\section{U.S. Department of Energy}




\section{DISCLAIMER}

This report was prepared as an account of work sponsored by an agency of the United States Government. Neither the United States Government nor any agency Thereof, nor any of their employees, makes any warranty, express or implied, or assumes any legal liability or responsibility for the accuracy, completeness, or usefulness of any information, apparatus, product, or process disclosed, or represents that its use would not infringe privately owned rights. Reference herein to any specific commercial product, process, or service by trade name, trademark, manufacturer, or otherwise does not necessarily constitute or imply its endorsement, recommendation, or favoring by the United States Government or any agency thereof. The views and opinions of authors expressed herein do not necessarily state or reflect those of the United States Government or any agency thereof. 


\section{DISCLAIMER}

Portions of this document may be illegible in electronic image products. Images are produced from the best available original document. 
NOTICE

This report was prepared to document work sponsored by the United States Government. Nelther the United States nor 1ts agents the United States Department of Energy, the United States National Aeronautics and Space Administration, nor any federal employees, nor any of their contractors, subcontractors or their employees, make any warranty, express or 1mplled, or assume any legal liability or responsibllity for the accuracy, complateness, or usefulness of any information, apparatus, product or process disclosed, or represent that its use would not infringe privately owned rights. 


\begin{tabular}{|c|c|}
\hline $\begin{array}{l}\text { 1. REPORT NO. } \\
\text { - DOE/NASA CR-150560 }\end{array}$ & 3. RECIPIENT'S CATALOG NO. \\
\hline \multirow{2}{*}{$\begin{array}{l}\text { 4. TITLE AND SUBTITLE } \\
\text { Solar-Heat Transport Fluids for Solar Energy Collection } \\
\text { Systems (A Collection of Quarterly Reports) }\end{array}$} & $\begin{array}{l}\text { 5. REPORT DATE } \\
\text { January } 1978 \\
\end{array}$ \\
\hline & 6. PERFORMING ORGANIZATION CIIDE \\
\hline 7. AUTHOR(S) & 8. PERFORMING ORGANIZATION REPOR' \# \\
\hline \multirow{3}{*}{$\begin{array}{l}\text { 9. PERFORMING ORGANIZATION NAME AND ADDRESS } \\
\text { Houston Chemical Company } \\
1 \text { Gateway Center } \\
\text { Pittsburg, Pennsylvania } 15222\end{array}$} & 10. WORK UNIT, NO. \\
\hline & $\begin{array}{l}\text { 11. CONTRACT OR GRANT NO. } \\
\text { NAS } 8 \text { - } 32255\end{array}$ \\
\hline & 13. TYPE OF REPOR' \& PERIOD COVERED \\
\hline \multirow{2}{*}{$\begin{array}{l}\text { 12. SPONSORING AGENCY NAME AND ADDRESS } \\
\text { National Aeronautics and Space Administration } \\
\text { Washington, D. C. } 20546\end{array}$} & $\begin{array}{l}\text { Contractor Report } \\
\text { Nov 15, } 1976 \text { - Nov 15, } 1977\end{array}$ \\
\hline & 14. SPONSORING AGENCY CODE \\
\hline
\end{tabular}

This work was done under the technical management of Mr. John Caudle, George C. Marshall Space Flight Center, Alabama.

16. ABSTRACT

This document consists of several quarterly reports that cover the progress made by the Houston Chemical Company, who is developing noncorrosive fluid subsystem(s) compatible with closed-loop solar heating and combined heating and hot water systems. The system is also to be compatible with both metallic and non-metallic plumbing systems; and any combination of these. At least 100 gallons of each type of fluid recommended by the contractor will be delivered, and a number of fluids will be performance tested.

These reports have been reformatted, and the pages renumbered. A limited amount of retyping and retracing has been done for legibility, and cost information has been removed.

\begin{tabular}{|l|l|l|l|}
\hline 17. KEY WOROS & 18. PISTRIBUTION STATEMENT \\
Unclassified-Unlimited
\end{tabular}


THIS PAGE

\section{WAS INTENTIONALLY LEFT BLANK}




\section{TABLE OF CONTENTS}

Page

Section I - First Quarterly Report

Section II - Second Quarterly Report

Section III - Third Quarterly Report

Section IV - Fourth Quarterly Report

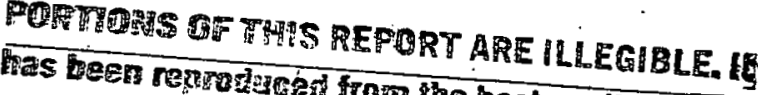
copy to permit the broadest possible avails ability. 


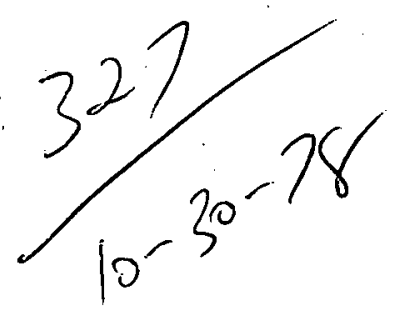

Recipients of DOE/NASA CR-150560 please replace page 13/16 with corrected page 15/16. 
QUARTERLY REPORT

CONTRACT NAS8-32255

SOLAR HEAT TRANSPORT FLUID

February 27, 1977

\footnotetext{
Prepared by:
}

Houston Chemical Company

Div. of PPG Industries, Inc.

P. O. Box 4026

Corpus Christi, TX 78408 
Summary

Contract Accounting System

Contract Delays

Schedule

Test Stand-Engineering

Plumbing Layout

Electrical

Instrumentation

Collector Panel Study

Collector Panels

Solar Heat Transport Fluids'

Instrumental Analysis

Solar Pump Tests

NASA Technical Manager Visits

Meeting at NASA, Huntsville

ASTM Meeting

Visit to NASA

Preliminary Design and Quarterly Reviews

Post-Award Conference

Forecast of Activities for Next Quarter

Potential Problem Areas 


\section{INTRODUCTION}

Very little information has been generated in the past relative to corrosion performance and freeze protection of solar heat transport fluids under actual conditions of solar energy collection systems. In many instances in which corrosion problems have been reported in conjunction with solar collector operation, the cause of the problem has not been properly analyzed and failures have often been attributed the wrong cause. In many cases, the selection of the solar system material and the solar heat transport fluid itself has been based upon information generaied under greatly different conditions. These differences in operating conditions can lead to severe corrosion problems in solar systems in some applications, even though these systems have been used successfully in other applications. These other applications can only be used as guidelines in designing new systems with the proper solar heat transport fluid.

The purpose of this project is to demonstrate a solar heat transport fluid which will provide corrosion and freeze protection for aluminum, copper, and steel solar collector systems using copper plumbing.

SUMMARY

The contract was initiated November 15, 1976 and work began at that time. Engineering drawings were upgraded and a site for the solar test stand was selected. A study was conducted to determine the proper selection of solar heat transport fluids, solar collector pane1s, and plumbing. Copper, aluminum, and steel collector panels and all copper plumbing were selected.

A meeting was held at Marshall Space 1 light Center to obtain approval for construction of the test stand and review a proposed revised Development Plan. A letter of approval of the test stand was received from Mr. John Caudle, NASA Technical Manager. The Development Plan was revised and approved by Murshall Space Flight Center. Preliminary screening of solar heat transport fluids was conducted and corrosion glassware and simulated service testing was initiated. All inhibited-solar.heat transport fluids have been screened by the above procedure. 
All major test stand engineering has been cormpleted. The test stand construction has been delayed due to abnomally high frequency of rainfall. An effort has been made to expedite construction of the test stand by removal of sod and placing of slacker sand to increase drainage so that paving can be layed. The test stand contractor is pre-assembling the structure before installation while waiting for paving to be completed.

Procedures are being developed and investigated for analyzing solar heat transport fluids to determine corrosion of the solar collector systems.

All necessary documents specified in the contract were prepared for the Preliminary Design Review and Quarterly Review. Discussions concerning the reviews were held at contractor's facility in Corpus Christi, Texas.

A Post-Award Conference was held with DCASMA on February 14, 1977. concerning aspects of the contract.

CONTRACT ACCOUNTING SYSTEM

This paragraph has been deleted.

\section{CONTRACT DFLAYS}

As reported previously, the site area (which was surveyed by Mr. John Caudle, NASA Technical Manager) is still waterlogged and the job stalled due to excessive and abnormal precipitation and inclement temperatures.. The current long-term 
forecast promises no immediate significant weather improvement. Some preliminary work has been done on the site arca such as removing of the sod and placing subgrade slacker sand. Some trees have been removed and some topography changes have been made. A drainage ditch will be relocated when weather permits to provide natural movement of casual water from site when surfaced.

Delays continue in fabricating typical steel and copper solar collector panel modules. A personal visit by the delegate of the Project Manager to the fabricator is planned to expedite production and delivery.

\section{SCHEDULE}

A program schedule (attached) has been completed and is layed out to show the actual work performed. A vertical dashed line indicates the end of this reporting period. As shown, the test stand construction is two and one-half months behind schedule due to paving delays caused by excessive and abnormal precinitation. All major test stand engineering has been completed and only minor changes are anticipated. Under Project Management all contractual requirements have been completed and are up-to-date. The Development/Qualification Tests phase is ruming on schedule.

\section{EXPENDITURES}

This section has been deleted.

\section{TEST STAND--ENGINEERING}

An area was studied for the best possible location of the solar test stand. Considerations were made concerning future PPG Industries projects; installation conveniently located to Houston Chemical Lab facility; removal or usage of solar energy; exposure to the south; and cost consideration. After selection of an appropriate site, a drawing was made showing the proper elevations for drainage, paving, test stand location, and fencing. The sire was then approved by the Plant Manager, PPG Industries in Corpus Christi.

The test stand structure was designed to the proper angle $\left(25^{\circ}\right)$ to maximize efficiency of the solar collector panels. The location of the 
collector panels on the test stand allows space for adequate accessibility for inspection, removal, and evaluation purposes. The structure was designed to carry the dead equipment load, live loads, and Gulf coast wind loads. The structure framing is constructed of Wolmanized-treated lumber and the plywood deck is epoxy-coated with a sand finish for skid protection.

PLURBING LAYOUT

The plumbing layout has been completed and details the location of solar collector panels, pumps, heat exchangers, expansion tanks, flowmeters, thermocouples, pressure relief, isolating valves, and plumbing.

Engineering is underway to modularize as a subsystem component the pump, expansion tank, heat exchanger and flowmeter for quick removal to a shop for repair, etc. as needed.

Unique in this solar system plumbing will be the use of isolating flanges rather than conventional globe or gate valves. This technique permits easy removal of system subsystems;'i.e., pumps and solar collector panels for whatever the purpose. No significant system fluid loss will occur, which otherwise might abort the test:

\section{ELECTRICAL}

Electrical layout for the test stand is completed. The layout incorporates the basic system which is $240 \mathrm{v}$. with underground feeders supplying $110 \mathrm{v}$. for the test stand. The layout also includes the following;

1. Breaker protected motors

2. Photoelectric solar actuated motor starter units

3. Test stand service lighting. Salvaged PPG equipment will be used to reduce costs

4. Service outlets for electrical needs to maintain the test stand

5. Service outlet to service instrumentation

6. Area will be lighted during hours of darkness. 
INSTRURENTATION

A data logger, Digitrend Model 220, with.a satellite to provide sufficient temperature data point monitoring capability, plus usual supporting accessories has been ordered. Temperature data is critical in defining the parameters of corrosion data.

This equipment will permit monitoring and recording of temperatures at 240 sensing points. As programmed now, the test stand will require 202 points. The extra capability of 38 points was ordered because it is the closest increment that can be ordered and the extra points allow for add-on thermocouples. Fisher and Porter rotameters have been ordered to monitor and control all thirty-seven system flow rates in the test stand. The purpose of a flowmeter within the scope of the contract work is to provide sufficient flow management to conform to our needs in corrosion studies. This type of flowmeter is adequate to monitor the various system flow rates within the design limits of the collector panels and where thermal efficiency testing is not involved.

COLLECTOR PANEL STUDY

A study was conducted by our technical staff which upgraded the latest information on the state of the art. Since the proposal was written in late 1975, the state of the art has shown some significant changes. Aluminum and steel have shown to be potential metals for collector panels.

We have revised the manner in which to utilize the sixty-four (64) panels available. Where initially we offered sixteen (16) test spots and utilized only copper collectors, we now provide thirty-six (36) active spots for testing plus a standby for non-metallic collectors study which we have mutually agreed is useful.

The initial set-up restricted the candidate opportunitics to coppor systems and seven candidates; the revised provides for seven candidates but also covers aluminum and steel collectors. We have spent considerable time reviewing the above with our technical staff and NASA technical staff. 
OOLLECTOR PNELS

The solar collector panels have been selected and ordered from PPG Gass Division and are as follows:

23 Aluminum solar collectors 34"x76"; double glazed float glass; Duracron coated aluminum roll bond panels with insulation and pans

$2:$ Unglazed aluminum roll bond panels

23 "Stecl solar collectors 34'x76"; double glazed float glass; Duracron coated Trant.er "Econocoil" steel panels with insulation and pans.

2 Unglazed steel Tranter pódels

23 Copper solar collectors 3.1" $\times 76$ "; double glazed float glass; Duracron coated roll bond panels with insulation and pans

2 Unglazed copper roll bond panels,

We have ordered two each extra of each type of solar collectors for replacement during testing. The unglazed panels are for initial surface inspection.

The roll bond construction was selected because we feel it is more prone to crevice corrosion than the tube sheet type of construction.

SOLAR HEAT TRANSPORT FLUIDS

Preliminary inhibited solar heat transport fluids have been screened for potential candidate fluids. Still to be completed are similar baseline un-? inhibited fluids such as water, monoothyleno glycol, propylene glycol, and glycerine for later correlation with candidate performances. Solar heat transport fluids are tested by the following procedures.

1. Glassware Corrosion Test Procedure (ASTM D1384)

This method covers a simple beaker-type procedure for

qvaluating the effects of engine coolant on metal specimens under controlled Iaboratory conditions. 
2. Simulated Service Corrosion Testing (ASTM D2570)

This method evaluates the effects of a circulating engine coolant on a metal test specimens and automotive cooling system components under controlled, essentially isothermal laboratory conditions. The method specifies test materials, cooling system components, type of coolant, and coolant flow conditions that are considered typical of current automotive use.

Both of these ASTM test procedures have been designed for automotive. coolant applications. Although there are simllarities, a solar energy system is not identical. There is an ASTM solar committee working on better procedures to screen solar materials in solar heat transport fluids. The Project Manager will make an attempt to follow and report to the George C. Marshall Space Flight Center current progress in these areas.

Since all testing and evaluations are not complete, separate report will be written and included in future reports.

\section{INSTRUNENTAL ANALYSIS}

A study has been conducted by an analytical chemist (PPG Chemical Research) to develop a procedure to analyze sample fluids for metals (copper, aluminum, iron, lead). The samples were taken from static test panels which have been on test for several months. The panels are copper and aluminum with all copper plumbing and steel expansion tanks.

- There was no increase in metal concentration in any of the samples of solar heat transport fluid'analyzed by the atomic absorption technique. Solids were filtered out of the solar heat transport fluid samples and analyzed semiquantitatively by emission spectroscopy. The cmission spectrographic analysis , indicated corrosion products were present in these solids.

Samples of the solar heat transport fluids from the glassware corrosion tests are being analyzed for metals and correlated with weight losses of metal coupons which were inmersed in that fluid. The aralyses indicate the following: 
1. There was essentially no correlation between the analysis of fluids and the weight loss observed for corrosion coupons.

2. The data in general indicated low solubilities of $\mathrm{Cu}, \mathrm{Fe}$, $\mathrm{Pb}$ and $\mathrm{Al}$ in the test fluids. This was particularly true for $\mathrm{Fe}$ while $\mathrm{Cu}$ was an exception showing reasonable solubility in the propylene glycol and. triethylene glycol formulations.

3. All test solutions were relatively solids-free indicating, in conjunction with the low dissolved metals contents, that corrosion products must have remained for the most part on the metals on which they were formed. The prospect of adequately monitoring corrosion rates by fluid and/or entrained solids analysis is, therefore, in serious, question.

4. Analytical observations:

a). The extraction efficiencies for $\mathrm{Cu}, \mathrm{Fe}$, and $\mathrm{Pb}$ from aqueous glycol solutions were very dependent on the glycol content. Calibration for any given extraction was, therefore, required for each specific glycol content involved.

b) For reasons as yet not understood, the efficiency for aluminum was higher from glycol solutions which had been used as test fluids than it was from glycol solutions which had not been so exposed.

A final report is now being prepared on the above subjects by PPG Industries, Corpus Christi Technical Center, Analytical Research Group and will be included in a later report.

On a parallel course, different methods and techniques are being evaluated such as coupons of system metals in test stand plumbing, and linear polarization apparati.

SOLAR PUNP TESTS

A pre-contract test of the pumps selected for the test stand continues. This is a continuous running test, until fallure. System utilized closed loop, applied heat, automotive coolant/antifreeze as a fluid (50-50 by volume, aqueous). 
Pump identification: Grundfos UPS 20-42

Test conditions: $1 / 20 \mathrm{HP}, 115$ v. $60 \mathrm{HZ}, 1$ phase, $85 w_{0}, 0.85$ a

Test started: $190^{\circ} \mathrm{F}, 3-5 \mathrm{psig}$ 1530 hours, $8 / 10 / 76$

Information concerning this test will be included in later reports.

\section{NASA TECHNICAL MANACER VISITS}

Two visits by Mr. John Caudle, Technical Manager, NASA, have been made through this period. At the initiation of the contract, he made a getacquainted visit and recently, on February 1, 1977, we had a combination Preliminary Design and Quarterly Review.

MEETING AT NASA, HUNTSVILLE (November 30, 1976)

A meeting was held at NASA in Huntsville to discuss the technical aspects of the contract. Those in attendance were:

John Caudle

$\cdot$

Al Krupnick

Bernie Wiesenmaier

Doug Franklin

Don Cramer

B. A. Bannon

John Wisnewski
MSFC Program Manager

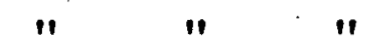

$S$ \& E Engr. Office

Materials \& Processes

Houston Chemical Company

"

"
1

"
3

11

The solar test stand was accepted by NASA and a letter to that effect was received from John Caudle. The selection of panels and fluids to be tested and our methods of testing were discussed and a revision in Appendix I (Development Plan) was agreed to so that we can evaluate aluminum, copper, and steel collector panels as mentioned in COLLECTOR PANELS above.

It was agreed that monthly sampling for wet chemistry which would include appearance, $\mathrm{pH}$ and reserve alkalinity would be acceptable. Also, viscosity, foaming, and ash content analysis would be initiated if panel fails or at end of test, whichever occurs first. The instrunental analysis on a bimonthly basis will not change, significantly the data value. 
During the meeting, we discussed the possibility of testing aluminum collector panels with black iron plumbing. We all thought this is a real possibility but it could not be considered in the scope of our current program. So in the near future, we will submit a proposal to evaluate aluminum collector panels with black iron plumbing.

Discussed details of contract documentation requirements and design reviews were made. The NASA personnel were very helpful in this regard.

ASTM MEETING (January 11-12, 1977)

The ASTM Subcomnittee E-21.10 on Solar Heating and Cooling Applications met on January $11-12,1977$ at the Dallas Sheraton. I sat in on a discussion of material performance. This group discussed future procedures to evaluate both materials and fluids. Rough drafts of these procedures are being prepared. I applied to join this ASTM Subcomittee and participate in the development of ASTM solar heat transport fluid standards and procedures.

VISIT TO NASA (January 25-27, 1977)

Meetings were held with several appropriate personnel set up by Itr. John Caudle, Technical Manager, NASA, which covered interpretation of the following , areas of the contract: Subsystem Performance Specifications (Appendix H), Verification Requirements (Appendix C), and Quality Assurance' Requirements (Appendix D). These meetings were of great help in preparing for the Preliminary. Design Review and Quarterly Review.

'PRELIMINARY DESIGN AND QUARTERLY REVIENS

These meetings were held at contractor's facility in corpus Christi, Texas on February 1, 1977. Those in attendance were:
John Caudle
John Wisnewski
Bernie Bannon
*Tom Baize

Participated in the general contract discussion only. 
The following items were discussed:

1. Review Item Discrepancy (RID) Tracing No. THC-1 dated 1/30/77; subject: Houston Chemical PDR - Verification Plan. This RID was "closed out" insofar as the contractor's action. The Verification Plan, subject of the RID, was handed to Mr. Caudle along with the original RID, properly executed. We understand NASA will approve this RID and supply a document to this effect for our file.

2. Subsystem Performance Specifications (Appendix $H$ ) was revised throughout as applicable and these documents given to Mr. Caudle. On January 26, contractor's Project Manger met with Mr. Caudle and others at NASA. An item by item review of the Residential and Commercial Interim Performance Criteria Summaries of the contract was made to make applicable to the project only such items as were involved with the solar heat transport fluid.

3. A draft of the program scheduling, as a bar chart, was evaluated and revised and readied for publication and use. Simplification of display and symbology 'was attained:

4. The Quality Assurance Plan was given to Mr. Caudle

5. General discussions covered:

A. Test stand construction

B. Plumbing layout

C. Instrumentation

D. Corrosion, with a visual examination of some glassware test coupons

E. A request for updated drawings, when available, for general information only.

6. Mr. Caudle visited the test site. He was given Polaroid photos showing the flooded area which document the impossibility of construction from flooding and subgrade water. 
POST-ANARD CONFERENCE

A Post-Award Conference was held on February 14, 1977 at the Houston Chemical Technical Center in Corpus Christi with Mr. Harry J. Stegmann of the Defense Logistics Defense Contract Administration Services Nanagement Area, San Antonio. Mr. Stegmann works out of the Harlingen, Texas office.

Initially the conference was set up with the DCASMA Office in Pittsburgh but since the NASA contract work was being accormilished in Corpus Christi, it was changed to the DCASMA, San Antonio office and the Harlingen office is a branch office which is closer to Corpus Christi. Mr. Stegmann was chosen to review the subject contract. There have been coimmications with Mr. Stegmann and John Caudle, Technical Manager, concerning this subject. The following items were discussed at the conference:

A. PORिQHASING ASPECTS

1. fack of competitive bidding on certain portions of project

2. Scope of records that should be kept for audit

3, Use of minority vendors on project and our difficulties with this problem

B.: CONTRACT MANAGER

1. Contract delays

2. Responsibilities

3. Inspection and auditing

4. Tour of facilities

C. ACCOUNTING

Members of the Accounting Department attended the conference.

FORECAST OF ACTIVITIES FOR NEXT QUARTER

1. Complete asphalt paving

2. Construction of test stand

3. Complete plumbing

4. Complete electrical installation

5. Delivery of solar collector panels 
6. Instrimentation delivery
a. Tenperature data logger
b. Flow meters
c. Thermocouples

7. Delivery of heat exchangers

8. Delivisy of cxpansion tanks

9. Continuc to cvaluate solar heat transfer fluids '

10. Instrimental analysis will continue to confirm techniques and improve.

11. Investigate alternate methods to evaluate corrosion in solar test systems

12. Prepare all necessary reports pertaining to the contract.

POTENTIAL PROBLLI AREAS

1. If rainy wather continues, it will delay paving and construction of the test stand stricturo.

- 2. Analytical procedures for analyzing metals in solar heat transfer fluid samples which would indicate true corrosion of solar systems could possibly be a problem.

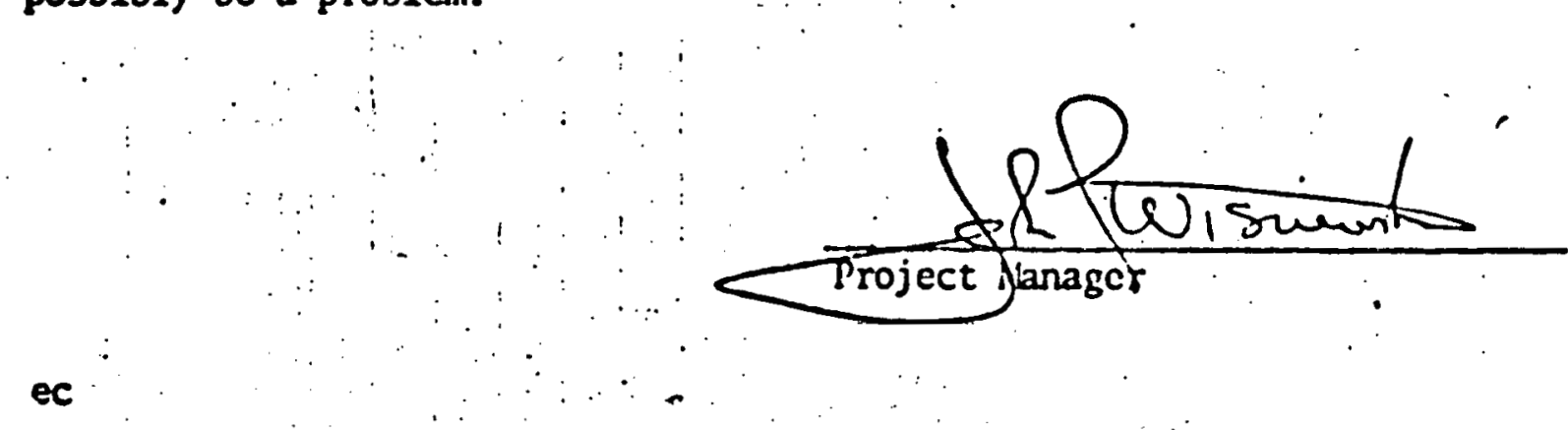

NOTE: Replace page $13 / 16$ with this page $15 / 16$. 
COMBINED QUARTERLY-MONTHLY REPORT

CONTRACT NAS8-32255

SOLAR HEAT TRANSPORT FLUID

May, 1977

Prepared by:

Houston Chemical Company

Div. of PPG Industries, Inc.

P. O. Box 4026

Corpus Christi, TX 78408 
INTRODUCTION

Very little information has been generated in the past relative to corrosion performance and freeze protection of solar heat transport fluids under actual conditions of solar energy collection systems. In many instances in which corrosion problems have been reported in conjunction with solar collector operation, the cause of the problem has not been properly analyzed and failures have often been attributed to the wrong cause. In many cases, the selection of the solar system material and the solar heat transport fluid itself has been based upon information generated under greatly different conditions. These differences in operating conditions can lead to severe corrosion problems in solar systems in some applications, even though these systems have been used successfully in other applications. These other applications can only be used as guidelines in designing new systems with the proper solar heat transport fluid.

The purpose of this project is to demonstrate a solar heat transport fluid which will provide corrosion and freeze protection for aluminum, copper, and. steel solar collector systems using copper plumbing.

SUMMARY

During this quarter we have been able to complete the basic structure of the test stand, plumbing modules, install solar collector panels, install solar plumbing, leak test solar plumbing, blend solar fluids, and have received all related solar hardware. Also, we have submitted a report entitled "The Deternination of $\mathrm{Al}, \mathrm{Cu}, \mathrm{Fe}$; and $\mathrm{Pb}$ in Glycol Formations by Atomic Absorption Spectroscopy."

Before testing of solar heat transport fluids can begin, some work remains to be done such as repair leaks, install heat rejection radiator, pump, flowmeter, and expansion tank, connect thermocouple wire to temperature data acquisition system, charge solar heat transport fluids in systems, and adjust flow rates.

\section{TEST STAND CONSTRUCTION}

Paving - complete

Basic Structure - complete except for completion of an office-type enclosure to house the data logger temperature instrumentation. A small air-conditioner will be installed to maintain the correct environment for this instrumentation. 
Plumbing - All thirty-seven plumbing modules which consist of a 15-gallon expansion tank, heat exchanger, 30 psi pressure relief valve, thermocouple ports at inlet and outlet of the heat exchanger, Grundfos pump with inlet and outlet isolation ball valves, gate valves at inlet and outlet of heat exchanger. Copper plumbing necessary to connect all components has been completely assembled and pressure-tested at 50 psig. Leaks were detected on the majority of the expansion and isolation valves' pipe-threaded connection. Only one solder connection leaked. In some cases the threads were retapped to clean up the threads and in other cases only tightening the threaded components was necessary to stop the leaks. We have concluded, by visual examination, that the pipethreaded ports are of poor quality. Since this experience, we visually examine all fittings before installation. It should be noted that all male pipe threads are wrapped with Teflon tape for a sealant. The modules have been installed in the proper test stand locations.

All solar collector panels have been installed along with plumbing connecting the solar collector panels to the plumbing modules. Two manifolds have been installed which connect the heat exchangers with the heat rejection system.

Plumbing Hardware - All hardware has been recceived.

Heat Rejection System - A separate closed loop system has been designed to reject the heat from the heat exchangers. The heat exchangers are connected to two manifolds, expansion tank, pump, and a horizontal hot water unit heater. Attached is a sketch of the system. . The hot water unit heater will be mounted on an outside wall of the test stand and the blower of the heater will draw air from under the test stand making the work area more comfortable during hot weather. During cold weather, the heater could be turned $180^{\circ}$ to heat the underside of the test stand. We are hoping to evaluate a separate fluid in this closed loop system. All the manifolds and plumbing to the heat exchangers have been completely installed.

Each system is being pressure tested and each pressure relief valve is being checked for cracking pressure and set at $30 \mathrm{psig}$, if necessary. Numerous leaks have been detected in ferrule connectors and all ferrule connectors have been replaced with solder connections. Leakage is still occurring at pipe-threaded connections at the solar collector panel isolation valves. These isolation valves were purchased from Grundfos Pump Company and, by visual examination, look of poor quality. A number of brass bushings were replaced due to leaking caused by blow holes in the cast bushings. 
Solar Heat Transport Fluid System - A drawing has been made identifying each component and heat rejection system. Attached is Drawing 64-A16994 of the system.

All solar fluids have been blended and characterization of physical properties has been completed.

Electrical - An electrical contractor has installed underground service, distribution equipment, electrical receptacles for pumps and lighting for the test stand. During the installation, changes were made on the electrical plan and detail Drawing 64-A16931. These changes are in the process of being revised on the drawing.

Instrumentation - All instrumentation has been recelved. The Digitrend 200 data acquisition system has been preliminarily checked out to be in good working order.

SOLAR HEAT TRANSPORT FLUIDS

Since all inhibited solar heat transport fluids have been screened and selected, it may not be necessary to test fluids until our solar test stand is in operation. This will enable us to concentrate all our efforts in setting up this operation.

\section{SOLAR COLLECTOR PANELS}

The solar collector panels selected previously have been changed from a double glazed to a single glazed configuration.

We believe that single glazed collectors to be tested for this project will perform more efficiently than double glazed collectors. We base this conclusion on the analysis of a domestic hot solar system analysis for the Corpus Christi area.

The results of the FCHART* computer analysis indicates that a PPG single glazed collector will supply 503,140 Btu/yr more than its double glazed counterpart, using the same collector area. The explanation behind this is that the loss in solar transmission due to the second lite of glass in a double glazed collector is not offset by reduced heat loss of the double glazed collector. Generally, this is true in warm climates such as we have in Corpus Christi.

*FOURT computer program developed by the Solar Energy Laboratory, University of Wisconsin, ladison, Wisconsin. 
Thus, we are confident that the single glazed coliectors will perform more efficiently, supply more energy, and provide useful service for this project.

The FCHART rims are enclosed for your information.

TEST STAND ENGINEERING

PPG Engineering is supporting the solar project by surveying solar test stand location for test stand contractor, and by following up on engineering work such as drawings changes.

SOLAR PUMP TEST

As previously reported in monthly and quarterly reports, the pre-contract testing of the pumps selected for the test stand continues. Test results will be included in later reports.

\section{TECHNICAL INFORMATION}

As mentioned in the Preliminary Design Review data package submitted to you in January, 1577, reports will be issued to support technical information as we acquire it. In keeping with this plan, ten copies have been sent to the Technical Manager, Mr. John Caudle of the report prepared by PPG Industries, Inc., Corpus Christi Technical Center entitled "The Determination of Al, Cu, $\mathrm{Fe}$ and $\mathrm{Pb}$ in Glycol Formulations by Atomic Absorption Spectroscopy."

\section{NEW TECHNOLOGY REPORT}

In compliance with our contract requirements for reporting new technology, we have set up a procedure for all employees involved in this contract. We believe this program will help us identify and report new technology as specified in the contract. Mr: A. D. Smith, Director of Technology Utilization Oifice, Marshall Space Flight Center, was nutified of our plan.

A New Technology Report has been filed with Nr. Smith's office on an all glass solar collector using a black fluid (see attached sheet). The advantages of an all glass collector are: (1) heating a black fluid by direct radiation; (2) reducing cost by replacing the metal collector with glass; (3) eliminating the corrosion problem of a metal collector; and (4) the mirrored surface will reflect lost energy back to black fluid. 
A visit was made to Olin Research Metals in New Haven, Comecticut, on March 1 to discuss solar energy corrosion problems. Olin is a major supplier of PPG's solar collector plates and is supplying two-thirds of the collector plates for the NASA solar contract. Matt Rupp, Marketing Manager for 01in, initially contacted me before the first of the year and expressed an interest in 0lin participating in the corrosion evaluation of our solar program. Through Matt, I contacted Jim Popperwe11, PhD, Associate Director, Chemical Metallurgy and Engineering Metals Research Laboratories in New Haven, Connecticut.

At the 0lin Research facility, I spent the day with Jim discussing corrosion and solar fluid properties which he has either investigated or is in the process of investigating.

The Olin Metals Research lab is a five-story building that must be at least 500 feet long and is staffed by 130 research personnel who work in the aluninum and copper alloys only. They have the capabilities to fabricate and evaluate any new alloy. last year approximately 115 patents were issued with only 130 personnel which includes two full time patent lawyers to process the patents.

The following items were discussed:

1) How Olin solar collector plates are manufactured

2) Corrosion characteristics in a solar system

3) The different types of corrosion effected by solar energy

4) How the different metals are affected by corrosion in solar panels

5) Why you need a solar fluid, freeze protection, corrosion protection, and boiling point

6) Inhibitors available and their mechanisms.

Jim made the following suggestions:

1) The automotive coolant ASTM methods' for evaluating glassware corrosion and simulated service may not apply. For example, the automotive and solar alloys are completely different.

2) Use a method to screen out fluids which would simulate solar use; methods are being developed.

3) Simulate our solar test close to a normal installation. Further evaluation to correlate worse case with baseline conditions may be desirable. 
4) Stagnation period every two weeks

Pick the weekend for stagnation

Shut the system down

5) Methods of evaluating corrosion products in solar collector panels should be further evaluated.

The above suggestions are being taken into consideration and will be evaluated as testing proceeds.

Jim mentioned he would be available to help us in these areas and we both agreed to think over the program and talk about it in the near future. I extended Jim an invitation to come to Corpus and he accepted.

\section{VISIT TO CALMAC}

I visited with John Armstrong of Calmac in Englewood, New Jersey on March 2. John is the Project Manager for two NASA solar energy projects. John and I discussed mutual contract problems and exchanged ideas. John gave me a tour of the Calmac facilities which I found very interesting and saw their Summat solar collector. We discussed testing their collector in the future and that we are leaving an open spot for their collector. John will contact me before a collector panel will be ready which should be at least a few months away.

\section{SCHEDULE}

A program schedule has been attached and is layed out to show the actual work performed. A vertical dashed line indicates the end of this reporting period. As shown, the project is three months behind schedule due to paving delays caused by excessive and abnomal precipitation and hardware delays. Under Project Management all contractual requirements have been completed and are up-to-date.

\section{EXPENDITURES}

This section has been deleted. 
1. Pepair remaining leaks in system

2. Conplete the installation of heat rejection system

3. Comnect thermocouple wire to data acquisition system

4. Charge solar heat transport system

5. Adjust system flow rates

6. Start testing

7. Evaluate Development Plan because of contract delays due to abnormal precipitation and hardware delays

8. Develop procedures to evaluate corrosion in solar collector panels

9. Prepare all necessary reports pertaining to the contract.

\section{POTENTIAL PROBLEM AREAS}

Changing the Development Plan to accommodate the contract objectives.

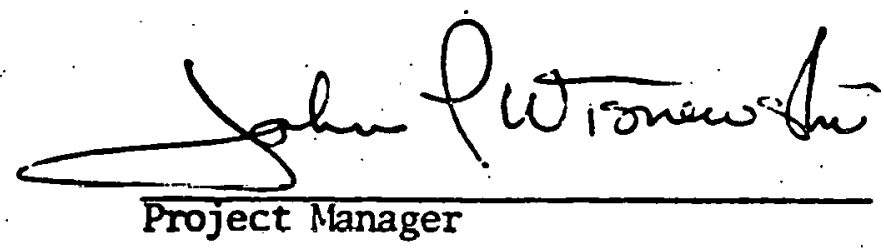




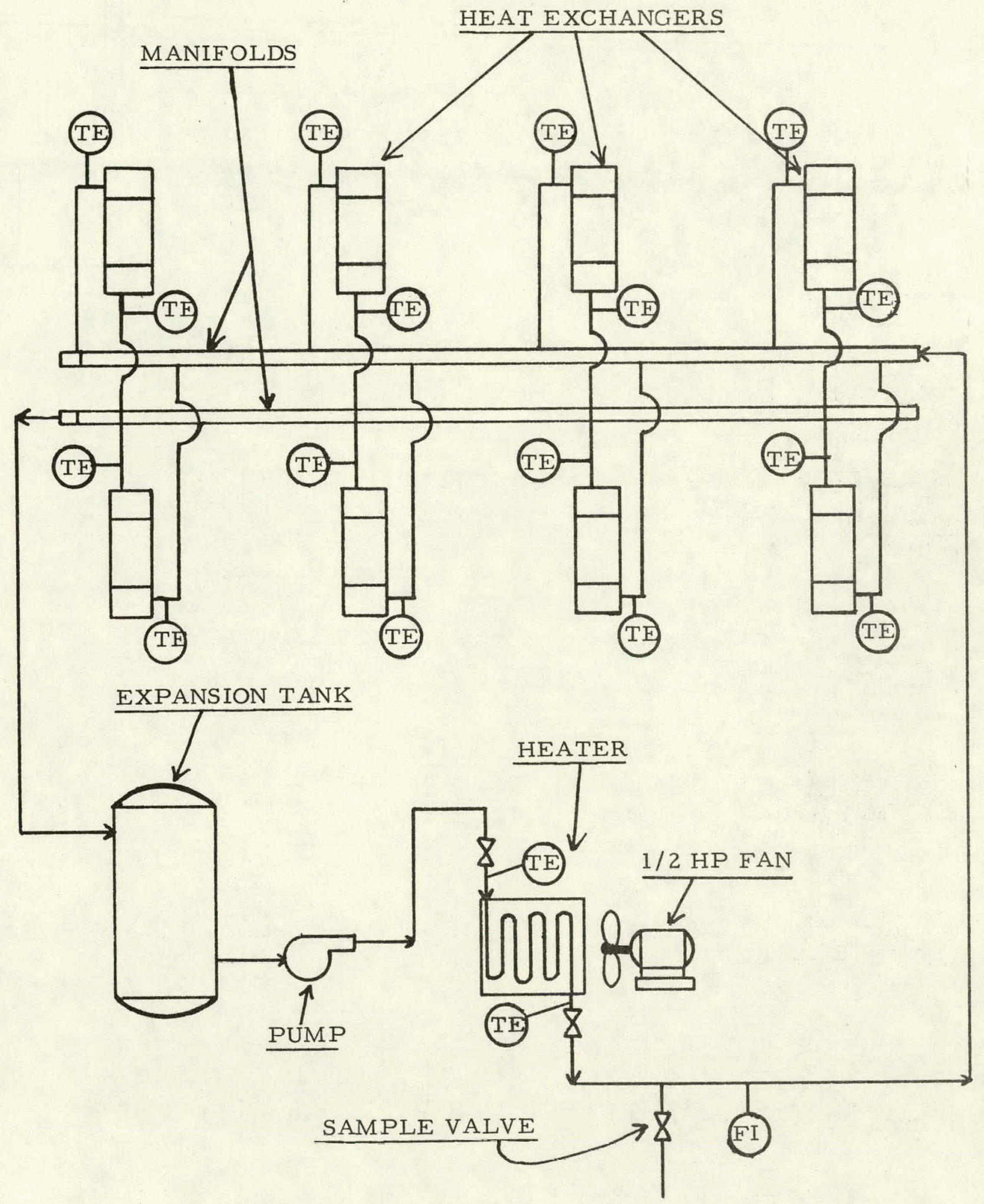

HEAT REJECTION SYSTEM

This drawing was redrawn for clarity. 


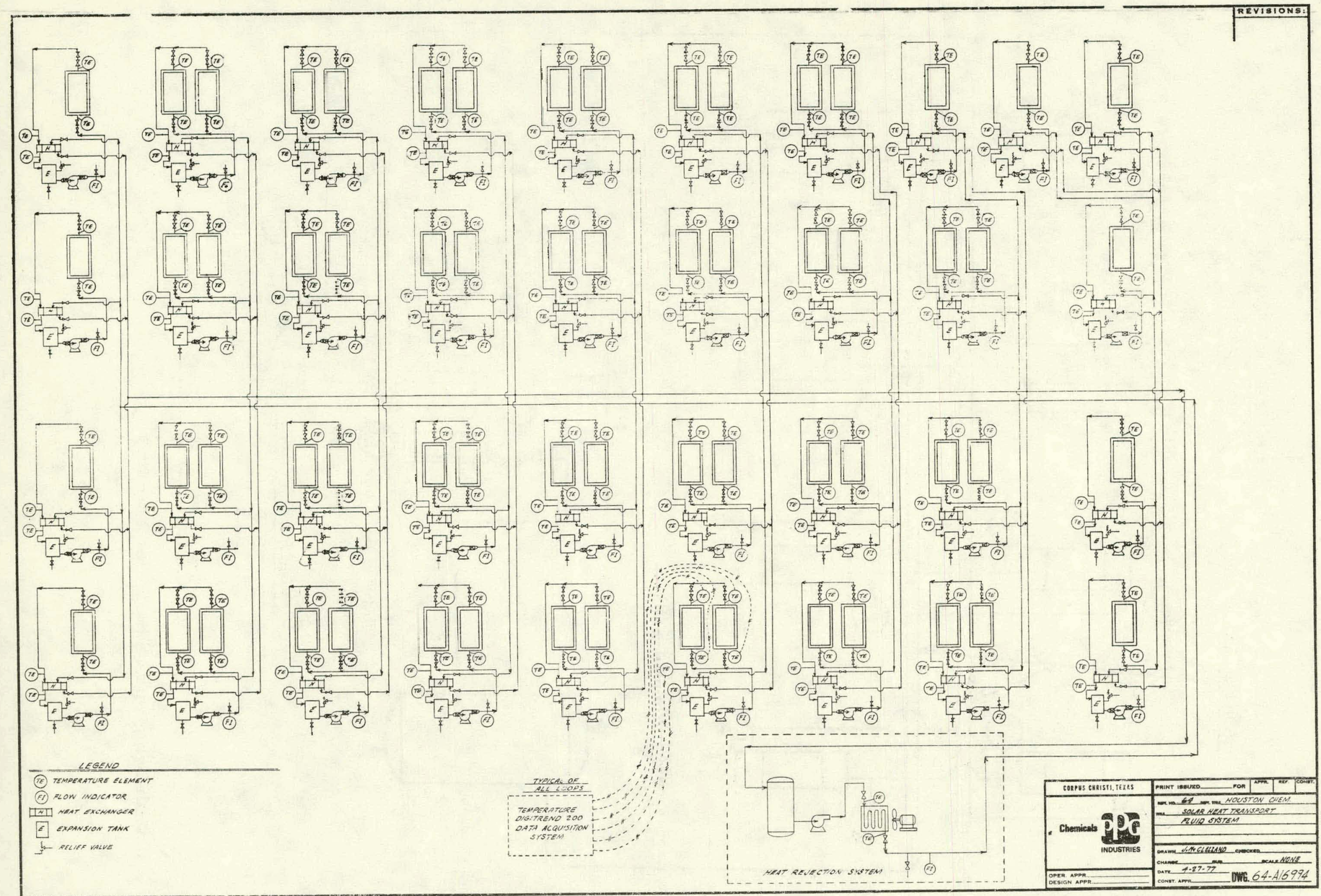




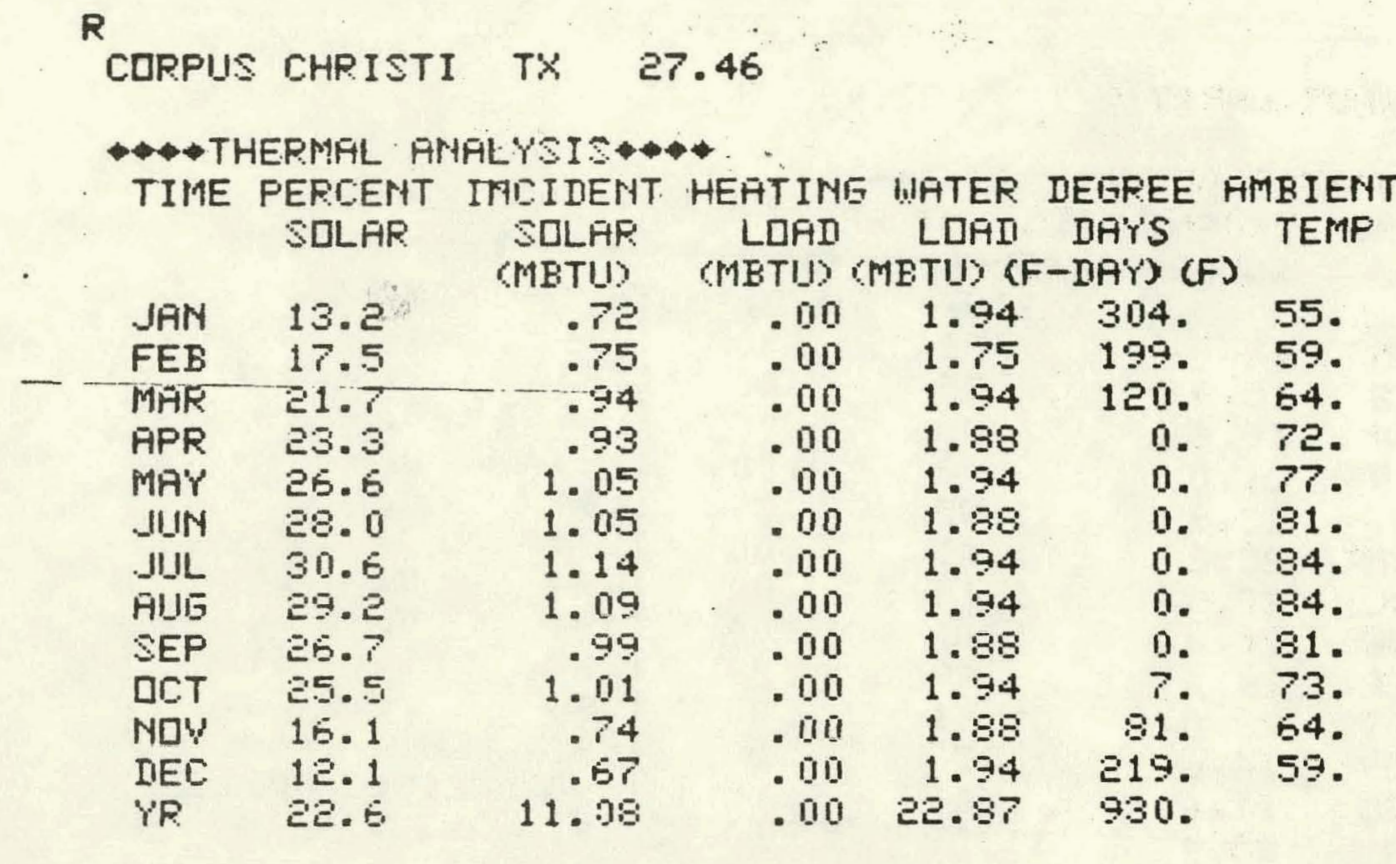

TYPE IN TITTF NUMBER AND NEW VALUE

PPG simgle glazed

$$
\begin{aligned}
& \text { Area }=18 \mathrm{sq} f t \\
& \text { load }=100 \mathrm{qul} / \mathrm{day}
\end{aligned}
$$




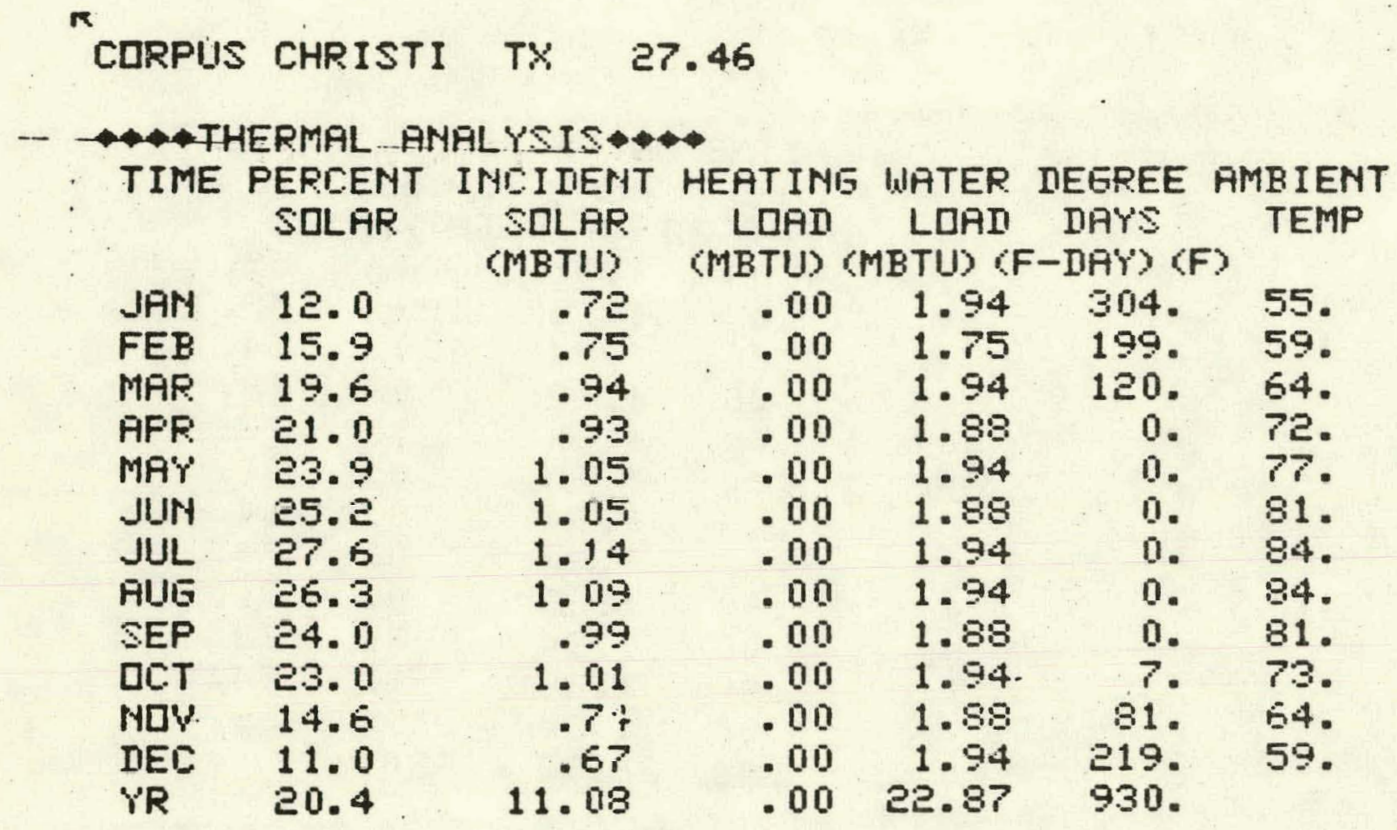

PPG double glazed

Collector

Area $=18 \mathrm{sq} \mathrm{ft}$

load $=100 \mathrm{gul} / \mathrm{day}$ 
HOUSTON CHEMICAL COMPANY, DIV. OF PPG INDUSTRIES, INC. Solar Energy NASA Contract No. NAS8-32255

NEW TECINOLOCY REPORT

SUMRARY (Attached sketch, if applicable)

An all glass solar collector using a black fluid. (See attached sheets.)

THE PROBLEY:

To gather solar energy.

THE SOLUTION:

To heat a solar fiuid using an all glass construction.

HON IT'S DONE:

A film of preferably black solar fluid flows through a special grooved

glass. The black fluid is heated directly by radiation from the sun.

A mirrored surface below the fluid will reflect lost energy back to the black fluid.

NOTES

The advantages of an all glass solar collector are: 1) heating a black

fluid by direct radiation; 2) reducing cost by replacing the metal collector

with glass: 3) eliminating the corrosion problem of a metal collector, and

4) the mirrored surface will reflect lost gnergy back to the black fluid.

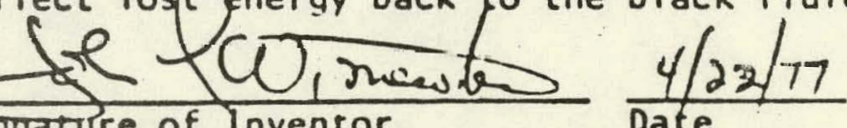




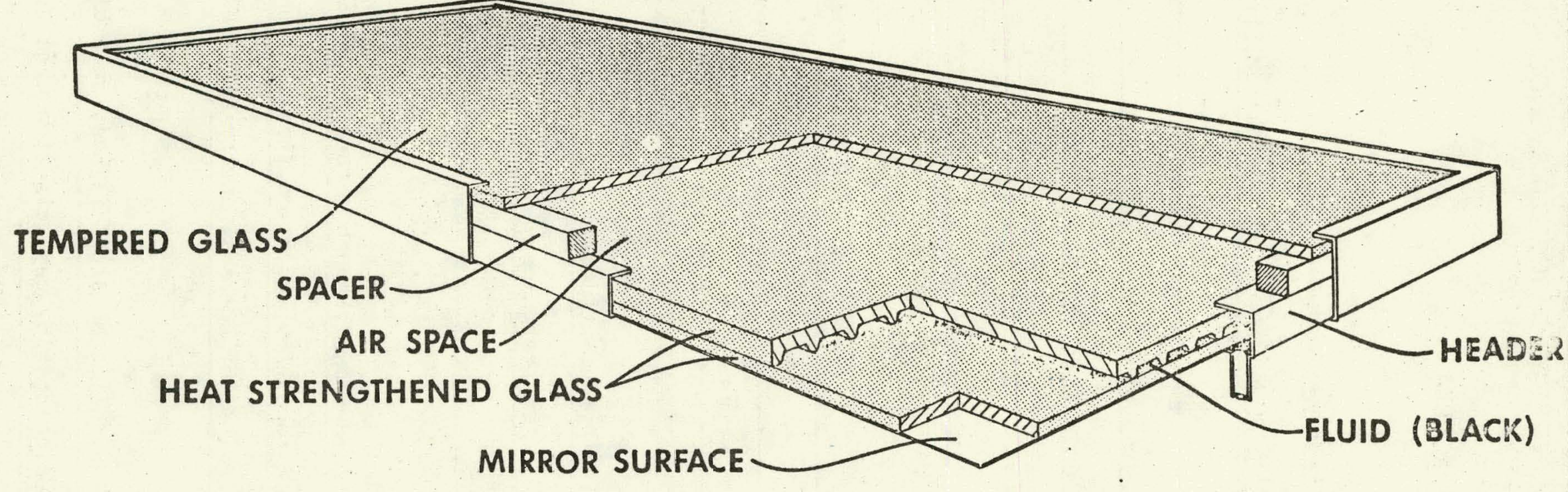

ALL GLASS SOLAR COLLECTOR 


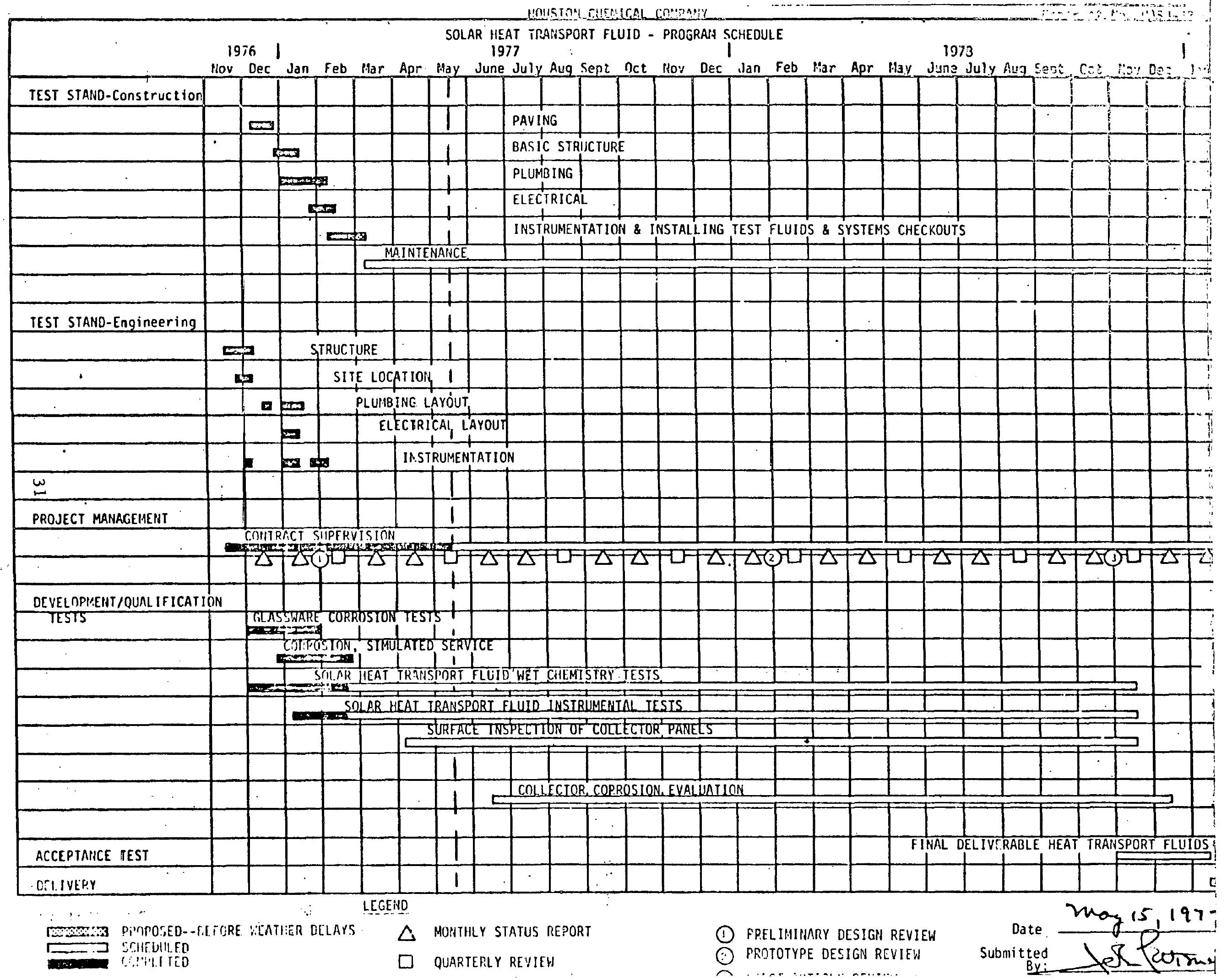


QUARTERLY REPORT

CONTRACT NAS $8-32255$

SOLAR HEAT TRANSPORT FLUID

August, 1977

Prepared by:

Houston Chemical Company

Div. of PPG Industries, Inc.

P. O. Box 4026

Corpus Christi, TX 7.8408 


\section{INTRODUCTION}

The purpose of this project is to demonstrate a solar heat transport fluid which will provide corrosion and freeze protection for aluminum, copper, and steel solar collectors using copper plumbing.

\section{SUMMARY}

The construction of the solar test stand has been completed to accommodate 37 separate systems with 64 solar collector panels. All systems were charged with their individual solar heat transport fluids. An addition fluid, triethylene glycol with a non-toxic inhibitor package in the heat rejection system, has been added to the list of fluids.

Methods are being studied to organize the solar test stand data to determine performance coefficients.

It was determined that air locking is occurring in one of the two parallel solar collector panels. Solar systems are being flushed periodically to relleve this problem, and we are now studying this problem to permanently prevent air locking from reoccurring.

\section{TEST STAND CONSTRUCTION}

Basic Structure - The basic structure has been completed which includes an office-type enclosure with a small air conditioner to maintain the correct environment for the data logger temperature instrumentation. Completion of an exterior plywood covering over the remaining test stand has not been.. completed.

Heat Rejection System - This closed loop system has been designed to reject the heat from the heat exchangers in each system. A hot-water heater unit is mounted on an outside wall of the test stand and the blower of the heater will draw air from under the test stand making the work area more comfortable during hot weather. During cold weather, a door can be adjusted to deflect the warm air to heat the underside of the test stand and office.

Plumbing - Each system has been pressure tested at 30 psig and all leaks repaired. Each pressure relief valve has been set at 30 psig cracking pressure. All plumbing has been completed.

Electrical - An electrical contractor has completed all electrical Installations which include photo-electric cells to turn on and off all solar systems.

\section{OPERATION OF TEST STAND}

Six Development operators were formally trained on data taking, systems operation, and system inspection. The operators' normal function is the operation of Development projects which are on three shifts covering 24 hours. 
Presently they inspect and operate the solar test stand on the following schedule:

\title{
Operators Inspection Schedule
}

\author{
10:00 hours \\ 14:00 hours \\ 18:00 hours \\ 22:00 hours \\ 6:00 hours
}

The operators inspect all plumbing for leaks, and solar collectors panels for damage. Flow and temperature data is taken when the systems are in operation during daylight hours, and during night hours the systems are inspected for possible leaks or other mishaps.

It was suspected that temperature readings were erroneous and a check out of thermocouples and temperature data logger was initiated. Thermocouples were disconnected from the temperature data logger and the same readings were obtained. Identical readings were obtained also with the terminals shorted or with a known voltage applied from a portable thermocouple tester.

A Doric data logger field engineer was contacted and following his suggestions, the entire terminal board of twenty units was disconnected. All points gave an "open" reading, but none of the other points were affected. The field engineer indicated there could be a defective MUX card which would affect other points in tho unit not even on the same board. All terminal strips were checked out. This apparently confirmed that the problem was on the MUX card. The field engineer came to Corpus and repaired a defective clip.

This left other temperatures still apparently defective. A point-topoint check was made of all 208 points using a portable instrument. Both Instruments agreed within about one degree on all points and a spot-check of several points with an ice bath agreed. It was suspected that ground loops from the thermocouples through the data logger could be the cause. If grounded back to the instrument, it could introduce extraneous voltages into the instrument. A check was made of the thermocouples and no ground loops existed.

It was finally decermined that the erroneous tcmperature readings were caused by the sular system. It was decided to check the solar collector panels for air locking. One of the two parallel collectors in a system was closed of $f$ and the other was flushed out for ten to 15 minutes. This procedure was then reversed to flush out the initial closed off collector. Flow was returned to both collectors and after approximately ten minutes, a temperature scan was lakeu. This showcd that the inlet temperatures were identical and exit temperatures were also identical. All solar collector systems were then flushed by the same procedure and all erroneous temperatures disappeared. 
After several days of running time, this same problem of air locking in the parallel. collector panels is reoccurring. Presently, we are flushing the collector panels to relieve this problem. We are now studying this problem to permanently prevent air locking from reoccurring.

\section{SOLAR HEAT TRANSPORT FLUID SYSTEM}

All systems have been charged with their individual heat transport fluids. The flow rates have been set at $0.5 \mathrm{gpm}$ per solar collector panel. An additional fluid in the Heat Rejection System has been added to the list of fluids. This is a closed loop system which will extend our area. of investigation. The fluid is triethylene glycol with a non-toxic inhibitor package. The following is a list of the type of solar heat transport fluids being evaluated:

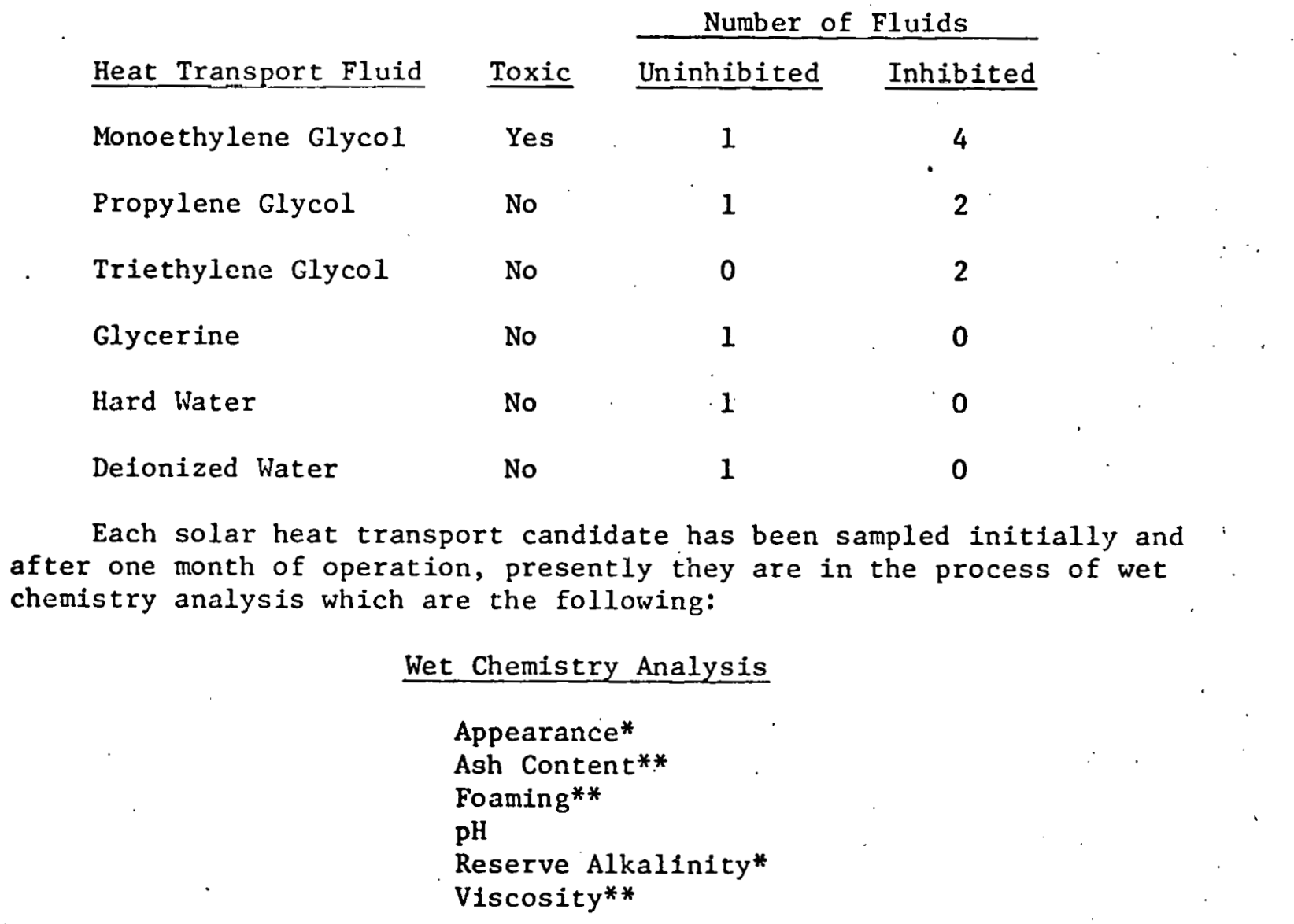

All solar heat transport fluids on test do not have dyes. The reason for havlug llo dyes is co give visual indication of the appearance of the solar heat transport fluids.

* Monthly tests

**Used if panel fails or at end of test, whichever occurs first 
The appearance of foreign particles similar to rust are being observed with systems using water as a heat transport fluid before one month of operation. The observance is being made through the system glass rotameter tubes. After samples have been analyzed, possibly the composition and source of the foreign particles may be determined.

\section{Instrumentation}

The Digitrend 200 data acquisition system has been calibrated and debugged by the manufacturers field engineer and he has instructed our personnel on the operation of the equipment. A study was conducted by PPG's electronic engineer to determine what would be the most economic way to service this equipment and after considering the possibilities of inhouse servicing and training, other local electronic service companies, the manufacturers service rates, and the manufacturers on-site service agreement, we chose the manufacturers on-site service agreement. The service agreement provides both preventative maintenance and unscheduled maintenance support. The unscheduled maintenance agreement insures 24 hour response, 5 days per week, excluding holidays, to our site for equipment repair. The cost of the service includes all necessary parts, labor, and travel will be covered by the basic monthly fee.

A high/low temperature alarm system has been designed using the existing data acquisition system. A telephone line connecting with a PPG Development control room will be connected. This will allow an alarm condition to be indicated at that location enabling an operator to correct the condition. The data acquisition system will also record what time the photo-electric cell turns on or off. The photo-electric cell energizes the starter crcuit for the pump motors.

Due to possible failure of the photo-electric cell, a by-pass switch has been installed to override the photo-electric cell enabling an operator to turn the solar system pumps on manually.

\section{DATA ORGANIZING}

A study is being conducted to organize the solar collector temperatures and flow data. A computer programmer is studying methods of using the data logger acquisition system to feed the temperature data in to our IBM computer. It would be necessary to keypunch the flow data to enter it into the computer since the flow readings are taken from rotameters.

Several methods have becn under conslderation to organize the folar collector temperatures and flow data. The following is a summary of the methods being considered.

1. The first method would require keypunching all temperature and flow data.

2. Use existing teletype (must be refurbished) for attaching to Doric Data logger to punch paper tape. A rental card punch with punched tape-to-card converter would be used to convert 
the tape to cards for submission to our IBM 360. Keypunched flow data could then be combined with the flow data.

3. Purchase a teletype with a built-in phone modem so that time sharing capability could be used with our IBM 370 in Pittsburgh. The temperature data would be transmitted from paper tape punched by the teletype to the IBM 370 back to magnetic tape on the IBM 360 in Corpus, where it would be combined with the keypunched flow data from cards for processing and storage.

4. Purchase a Hewlett-Packard 2645 data terminal for logging the data on a magnetic tape cassette. The data on the cassette would then be processed through the IBM 370 in Pittsburgh for conversion to our IBM 360 tape format. The data would then be processed as in method 3 above. The reliability of this system should be higher than the paper tape system.

\section{TEST STAND AREA}

A PPG safety team inspected the solar test stand and their recommendations are being followed up.

The installation of a six-foot chain link security fence has been Installed around the perimeter of the Solar Energy Test Stand.

\section{HURRICANE PROTECTION}

A study was conducted to protect the Solar Test Stand against a hurricane. Since the test stand was designed to carry Gulf Coast wind loads for this area, the solar collectors and solar heat transport fluids were our main concern. A telephone consultation with PPG Glass Division suggested that we need protection from small flying projectiles traveling at less than hurricane winds of $75 \mathrm{mph}$. Breaking the 1/8" Herculate glass by a flying projectile and damaging the solar collector plate, and possibly losing the solar heat transport fluid aborting months or a year of testing would certainly be costly and a blow to our program. To prevent flying projectiles from damaging the solar collectors, we are in the process of cutting 1/2" CDX plywood for each solar collector. The plywood will be stored and, in case of a hurricane warning, will be fastened to the $2 \times 6$ solar panel wooden frame with double head nails.

After the hurricane warning or hurricane, the plywood can be easily removed and stored for other hurricane warnirgs. The last hurricane to hit Corpus Christi was Celia in 1970.

\section{TEST STAND ENGINEERING}

PPG Engineering is supporting the solar project by monitoring test stand installation and by following up on engineering items such as drawing changes. 


\section{SOLAR PUMP TESTS}

The Grundfos pump is still running on a continuous closed loop test.

\section{SCHEDLLE}

A program schedule is attached and is layed out to show the actual work performed.

\section{EXPENDITURES}

This section has been deleted.

\section{FORECAST OF ACTIVITIES FOR NEXT QUARTER}

1. Continue to perform shake down test on solar system. Air locking in parallel solar collector panels is causing hand flushing of parallel systems periodically.

2. Sample all solar heat transport fluids every 30 days and evaluate them for deterioration and general perforinance by appearance; $\mathrm{pH}$ and reserve alkalinity analysis. Additional analysis for ash content, foaming, and viscosity will be made if a solar collector panel fails or at the end of the test period whichever occurs first.

3. Evaluate the NASA Energy Contract Development Plan and determine the effects of contract delays due to delayed construction (bad weather), and recent test work which shows that another method of determining corrosion rates will be required.

4. Design and install a Hi/Lo temperature alarm for the test facility.

5. Develop procedures to determine when a solar collector panel fails and determine how to open collector panel internal passages for examination and determination of the corrosion rate. panels.

6. Study methods to eliminate air locking in parallel solar collector

7. Install safety railing on back and sides of solar test stand.

8. Install partial covering on solar test stand.

9. Study freeze protection of solar systems which contain water as a solar fluid. 
10. Write a computer program which will organize flow and temperature data and calculate heat transport coefficients:

11. Operate solar test stand.

POTENTIAL PROBLEM AREAS

1. Air locking of parallel solar collector panels.

2. Changing the Development Plan to accommodate the contract objectives.

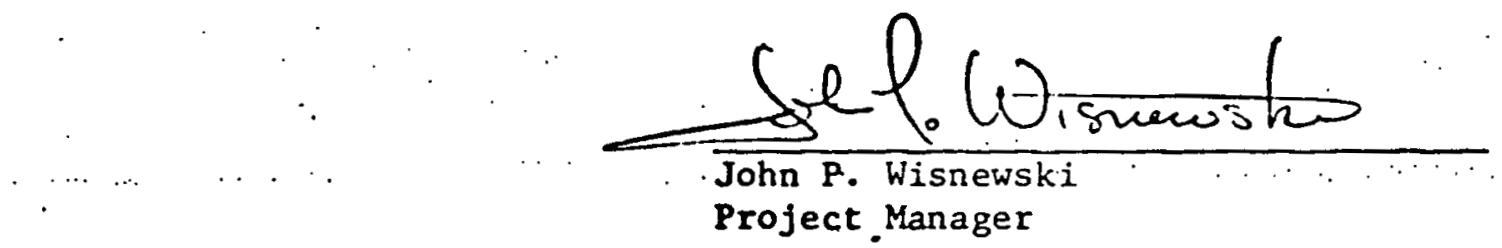

39 


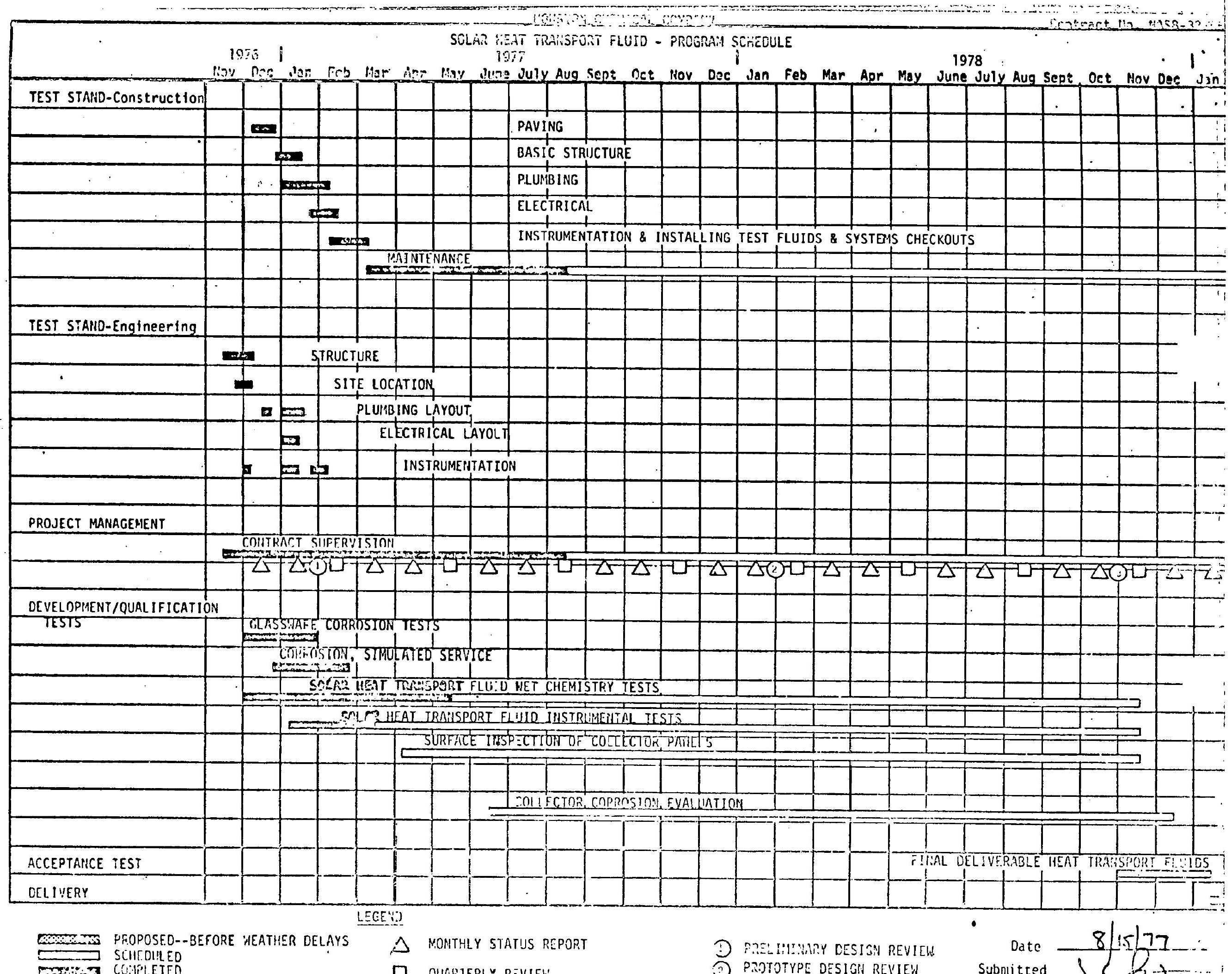


QUARTER LY REPORT

CONTRACT NAS8-32255

SOLAR HEAT TRANSPORT FLUID

November, 1977

Prepared by:

Houston Chemical Company

Div. of PPG Industries, Inc.

P. O. Box 4026

Corpus Christi, TX 78408 
The purpose of this project is to demonstrate a solar heat transport fluid which vill provide corrosion and freeze protection for aluninum, copper and steel solar collectors using copper plumbing.

\section{SURMARY}

Evaluation and testing of the solar heat transport fluids are continuing. A new appearance testing procedure of the fluids is being developed. The temperature alarm system has been completed but problems are reoccuring with the telephone lines. The Doric data logger has been repaired several times during this period by a Doric field engineer. The computer program to organize data has been completed and presently being debugged. Electrical heaters have been installed in six systems contalining wacer co provide freeze piu= tection. A non-metallic solar collector panel is being fabricated for testing with an aqueous fluid. Safety handrails have been installed around the lest stand. Enclosure of the north side of the test'stand has been completed.

\section{OPERATION OF SOLAR TEST STAND} basis.

Testing of the solar heat transport fluids is continuing on a 24-hour

The air locking has reoccurred in the systems which have the two parallel solar collector panels. These systems were flushed by the following technique. One of the two rarallel collector valves are closed for 10 or 15 minutes, allowing the total flow of 1 GPM to pass through the one collector. This process is then repeated for the other solar collector panel. On an average weekly basis 23 collectors were flushed. During a 23-day period two; systems were flushed a maximum of 6 times each and the minimum two systems did not need flushing.

System tank pressures were monitored and found to be fluctuating from a pressure to a vacuum depending on the heating or cooling of the system. The majority of the time the system would be under a vacuum, see figure 1 . The maximum pressure recorded is 5.2" $\mathrm{Hg}$ pressure and the minimum is $-4^{\prime \prime}$ Hg vacuum.

Since the collector design due to the outlet being at $90^{\circ}$ to the plane of the collector plate docs not allow venting at the highest point of the collector. This design can allow air to be trapped at this point. Wn believe the design of the outlet tube could lead to similar problems in other installations if parallel flow is used.

Methods to solve the air locking problem were discussed with the solar pump manufacturer (Grundfos), PPG Solar System Engineer, the collector plate manufacturers, and NASA System Specialist. The following is a sumnary list of methods discussed:

1. Pressurizing the tanks with nitrogen and air 
2. Higher flowrate to increase the velocity of the fluid forcing air out

3. External pressurized tank with diaphragn sealing air from solar fluid

4. Instaliation of an air purger at exit of the pump. This separates aix from the solar fluid before it enters the solar collector panel.

5. A combination of 3 and 4 .

It was decided under consultation with NASA's System Specialist that. pressurizing the systems with 10 psi air would be the simplest and least expensive to retrofit. Air was chosen over nitrogen because it would be more severe than nitrogen. Air would tend to oxidize the solar heat transport fluid more readily. Pressurizing the system with 10 psi would relieve the possibility of purup cavitation and would raise the boiling point of the solar fluids approximately $25^{\circ} \mathrm{F}$ disallowing the possibility of air expanding out of the fluid when heated in the solar collector.

Plumbing alterations have been completed so that each system can be pressurized with 10 psi air. The alterations consisted of replacing a $1 / 2$ " NPT pressure relief valve with a $1 / 2 "$ NPT 4-way cross and close nipple. Installing a pressure gage 0-30 psj, a tire valve which will allow charging the systens with air, and reinstailing tile pressure relief valve.

Each system was charged initially with 10 psi air and this pressure was adjusted early in the morning. During the day as the fluids were heated, the pressure in some instances would reach over 20 psi. The pressurizing ias eliminated the majority of air locking, but some systems are more prone to air locking than others. This is hard to explain since the systems are identical. The only possibilities might be the pump manufacturing tolerances and solar collector plate.passages might vary. This occurence will be watched as testing continues. The present plans are to continue to flush a system when necessary.

\section{SOLAR HEAT TRANSPORT FLUIDS}

Samples of the solar fluids are being taken monthly and analyzed for appearance, pll, and reserve alkalinity. They are compared with the initiel wet chemistry analysis. The computer program that was written to tabulate the monthly wet chenistry data has been modified to include the present concentratlun of the solal hcat traneport fluids (ronc. pet.), the original $\mathrm{pH}$ (orig. $\mathrm{pH}$ ), the present $\mathrm{pH}$ (pres. $\mathrm{pH})$, the original reserve alkalinity, preseul tustive alkalinity, and apparances The format will enable the reader to compare the original and present results. These reports are enclosed.

System 38, the fluid in the heat rejection system which is common to all heat exchangers, shows a decrease in reserve alkalinity from 10.6 to 3.3. This was caused by dilution by water in the heat exchangers and 
piping which was impossible to drain when the fluid $(\mathrm{T}-2)$ was added. The fluid was formulated at originaliy a $60 \%$ concentration. A higher concentration would have been chosen but the inhibitor, package would not go into solution. Since the heat rejection system operates at lower temperatures than the systems with solar collectors and is less prone to corrosion. because it contains all plastic tubing, steel tank, and copper tubing in the heat exchangers, we consider the system to have adequate freeze and corrosion protection.

The appearance of the test fluids seem to be changing by the visual inspection given on the wet chemistry malysis report. This is a visual test and is not compared to a standard. Procedures are being developed so that a more meaningful descriptive relationship will be used to define the color of sample taken.

There are two basic methods of color determination which we are studying. The first is PPG method \#73, "Determination of Color of Liquid Samples Referred to the Platinum-Cobalt Scale".

The determination of color of a liquid sample referred to the platinum cobalt scale is based upon a visual comparison of the sample and a distilled water sample containing a measured volume of standard "500 - color" reagent. The sample must be free of suspended matter and must be entirely clear ard transparent. Deeply colored samples cannot be determined by this method. The method is reproducible to 2-3 color units for samples having a color less than 30 .

The second method is using the Hellige Aqua Tester which distinguishes between color differences. Samples are placed in Nessler sample tubes with a long viewing depth to increase intensity of colors. Thus by matching sample colcr with standard colors. The concentration is read on the standard color disc, which has a range from $0-70$ units.

The Hcllige Aqua Tester is simplest and most clear cut method, but the range of solar heat transport fluid samples go beyond 70 units. We are presently investigating purchasing a color disc with units greater than 70 .

\section{DATA LOGGER ACQUISITION SYSTEM}

A high/low temperaturc alarm system has been installed. A telephone line connecting with a PPG. Development control room has been connected. This allows an alarm condition to be indicated at that location enabling an operator to correct the condition.

Alarm difficulties have been experienced which are blamed on faulty telephone lines. Portions of the telephone lines have been replaced by Southwestern Bell, but difficulties are still occurring. We have requested several times that Southwestern Relj. repair these telephone lines to maintain satisfactory alarm performance. Southwestern Bell is sending out repairmen to solve this problem. 
Several times during this period the Doric data logger first 100 temperature readings went faulty and it was necessary for the Doric field engineer to service the unit. Labor and parts are covered by a service contract. During his last service call the problem was traced to intermittent failures in the power supply, and he replaced it.

\section{DATA ORGANIZATION}

A study has been conducted of various methods of organizing the solar collector temperature and flow data to determine solar collector performance coefficients. It was determined that the most economical method would be to take data at solar noon and keypunch all data on a daily basis. A computer program has been written and is being debugged to process and calculate the solar collector temperature and flow data to determine solar collector performance coefficients with collector corrosion performance.

\section{FREEZE PROTECTION FOR SYSTEM CONTAINING WATER}

The six systems with only water need freeze protection. Due to irradiation of the solar collectors on a still clear night, we understand the ambient temperature could be 10 or $15^{\circ} \mathrm{F}$ above the freezing point of water and the water in the collector panel could freeze. The system tank and heat exchanger were wrapped with fiberglass insulation. Flexible hcating tape was wrappar and insulated on the copper inlet tubing to the solar collector panel. Since the test was conducted during the day a plywood cover was placed over the solar collector. The pump was set at 0.5 GPM with the electrical heater on the collector panel outiet temperature after two hours of testing rose froin. $95^{\circ} \mathrm{F}$ to $112^{\circ} \mathrm{F}$. Since there is a PPC Development operator on duty 24 hours a day, when the ambient temperature reaches $45^{\circ} \mathrm{F}$ he is instructed to turn the heaters and pumps on. The installation of the electrical heaters and insulation has been completed on all six systems containing water.

\section{TESTING OF NON-METALLIC SYSTEM}

I. have been informed by Calmac in Englewood, New Jersey, a non-metallic manufacturer of solar collector panels, that they are now in positjon to supply us with their version of a non-metallic solar collector panel. Calmac is now completing a contract with NASA to develop a non-metallic collector panel. The NASA technical nanager, John Caudle, has suggested that we work with Calmac.

An open space has been left for such a collector as agreed to in the contract. Calmac will fabricate the panel to fit our standard $18 \mathrm{ft}^{2}$ solar collector.

An aqueous test fluid will be chosen which will be compatible with the Calmar collector. 
It was determined by a management safety team that due to the height of the roof and that its slope is greater than the OSHA maximum, some means would be necessary to protect individuals working on the roof of the solar test stand. A safety railing was determined to be the most economical method to provide the protection and meet oslih's requirements. The handrailing is completed and is constructed of Wolmanized-treated lumber.

\section{SOLAR TEST STAND COVERING}

- During the winter months at times the north winds are chilling and could cool the exposed solar systems abnormally. It was decided to cover the north side of the test stand with $3 / 8^{\prime \prime}$ cedar plywood to protect the systems. Windows were installed to give ventilation during the hot months. This construction has been completed.

\section{TEST STAND ENGINEERING}

PPG Engineering is supporting the solar project by monitoring test stand installation and by following up on engineering items such as drawing changes. Encicsed is a schematic drawing of the revised solar test stand system plumbing.

\section{SCHEDULE}

A program schedule is attached and is layed out to show the actual work performed.

\section{EXPENDITURES}

This section has been deleted.

\section{FORECAST OF ACTIVITIES FOR NEXT QUARTER}

1. Sample all solar heat transport fluids every 30 days and evaluate them for deterioration and general performance by appearance, $\mathrm{pH}$ and reserve alkalinity analysis. Additional analysis for ash content, foaming, and viscosity will be made jf a solar collector panel fails or at the end of the test period whichever occurs first.

2. Evaluate the NASA Energy Coniract Development Plan aud determine the effects of contract delays due to delayed construction (bad weather), and recent test work which shows that another method of determining corrosion rates will be required. 
3. Develop procedures to determine when a solar collector panel fails and determine lin to open collector panel internal passages for examination and determination of the corrosion rate.

4. Develop a solar heat transport fluid appearance test procedure.

5. Debug the computer program which will organize flow and temperature data and calculate heat. transfer coefficients.

6. Operate solar test stand.

POTENTIAL PROBLEM AREAS

1. Changing the Development Plan to accommodate the contract objectives.

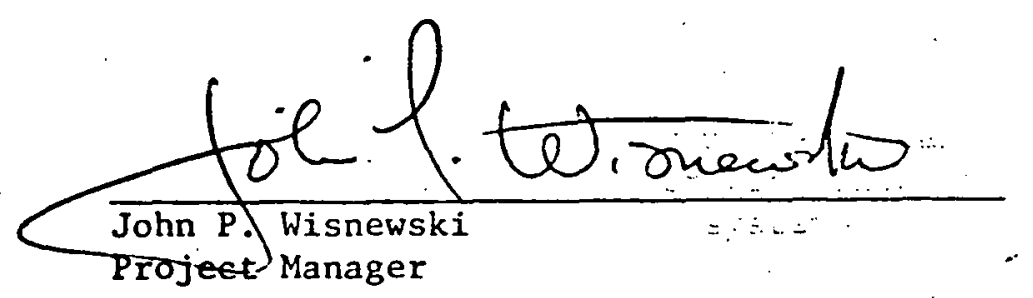

47 


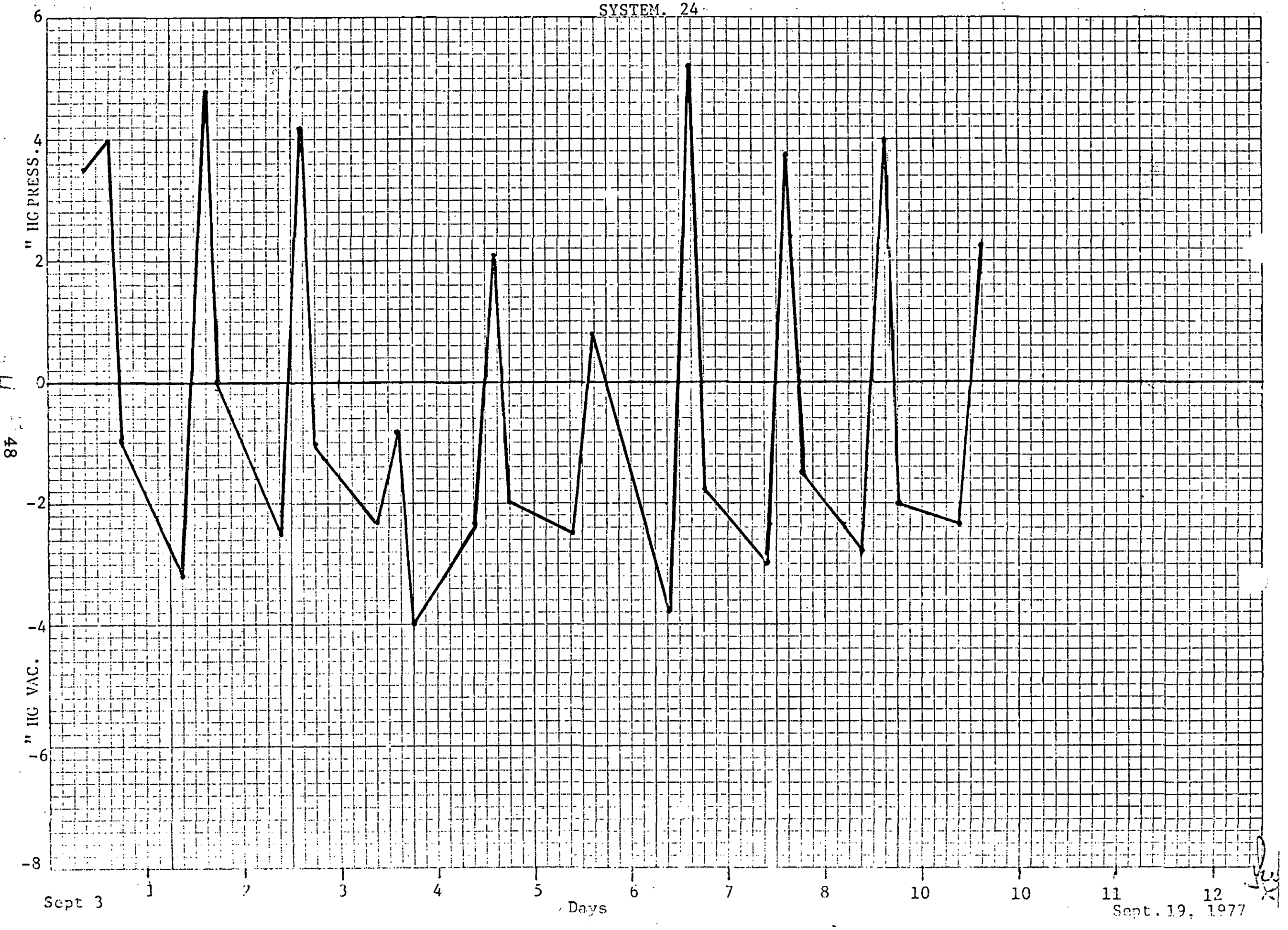


SYSTEM MAT. FLUID CUNC. DRIG. PRES. JRIGIVAL PRESENT
PCT. PH PH RES.ALK. RES.ALK. APPEAR

\begin{tabular}{|c|c|c|c|c|c|c|c|c|c|}
\hline 2 & $c U^{\circ}$ & $P-0$ & 46.7 & 5.2 & 6.4 & $\mathrm{LT}$ & 0.100 & LT 0.100 & YELLOW \\
\hline 3 & $A L$ & $P-Q$ & $51 \cdot 2$ & 5.2 & 5.0 & LI & 0.100 & LT 0.100 & YELLOW \\
\hline 4 & STL & $P-0$ & 51.1 & 5.2 & 5.1 & LT & 0.100 & LT 0.100 & YELLOW \\
\hline 5 & $\mathrm{Cu}$ & $M-0$ & 49.9 & 7.0 & 5.1 & $\mathrm{Lr}$ & 0.100 & $L T 0.100$ & RUS T \\
\hline 6 & $A L$ & $M-0$ & 50.1 & 7.0 & 5.2 & $L T$ & 0.100 & LI 0.100 & YELLOW \\
\hline 7 & STL & $M-0$ & 50.0 & 7.0 & 5.3 & LT & 0.100 & LT 0.100 & RUST \\
\hline 8 & $\mathrm{CU}$ & $D-W$ & 100.0 & 7.1 & 7.0 & $L T$ & 0.100 & LT 0.100 & SEDIMENT \\
\hline 9 & $A L$ & $D-W$ & 100.0 & 7.1 & 7.2 & $L T$ & 0.100 & $L T 0.100$ & TURBID \\
\hline 10 & STL & $D-W$ & 100.0 & 7.1 & 5.9 & L T & $0.10 n$ & LT 0.100 & $Y E L L O W$ \\
\hline 11 & $\mathrm{CU}$ & $G-0$ & 59.8 & 5.5 & 5.1 & $\mathrm{LT}$ & 0.100 & $\mathrm{LT} 0.100$ & YELLOW \\
\hline 12 & Cu & $T-1$ & 51.0 & 9.6 & 10.0 & & 6.100 & 6.050 & YELLOH \\
\hline 13 & $\mathrm{CU}$ & $P-2$ & 51.6 & 9.8 & 10.0 & & 6.250 & 6.150 & 6000 \\
\hline 14 & $\overline{C U}$ & $p-1$ & 51.9 & 9.8 & $9 . \overline{6}$ & & 6.000 & 5.900 & 6000 \\
\hline 15 & $\mathrm{CU}$ & $M-4$ & 51.0 & 9.4 & 9.4 & & 6.650 & 6.500 & G000: \\
\hline 16 & $\mathrm{Cu}$ & $M-3$ & 51.0 & 9.5 & 9.4 & & 6.650 & 6.500 & GoOn \\
\hline 17 & $\mathrm{CU}$ & $M-2$ & 52.5 & 8.8 & 8.9 & & 11.450 & 11.350 & SEOIMENT \\
\hline 18 & $\mathrm{Cu}$ & $M-1$ & $5 ? .5$ & 9.4 & 9.3 & & 9.900 & 9.200 & DEBRIS \\
\hline 19 & $\mathrm{Cu}$ & $H-W$ & 100.0 & 8.2 & 8.2 & $L T$ & 0.100 & LT 0.100 & SFDIMENT \\
\hline 20 & $A L^{-}$ & $6 / 0^{\circ}$ & 59.9 & 5.5 & 5.3 & $\mathrm{LT}$ & 0.100 & $\mathrm{Lr} 0.100$ & YELLDG \\
\hline 21. & $A L$ & $T-1$ & 50.9 & 9.6 & 10.5 & & 6.100 & 6.000 & $Y E L L O K$ \\
\hline 22 & $A L$ & $p-2$ & 51.9 & 9.8 & 10.4 & & 6.250 & 6.230 & j000 \\
\hline 33 & $\overline{A L}$ & $p-1$ & 52.4 & 9.8 & 10.6 & & 6.000 & 5.000 & $\therefore L E A R$ \\
\hline 24 & $A L$ & $M-4$ & 52.0 & 9.4 & 0.5 & & 6.550 & 6.700 & ELEAR \\
\hline 15 & $A L$ & $M-3$ & 52.0 & 9.5 & 9.5 & & 0.550 & 6.650 & SLEAR \\
\hline
\end{tabular}


$\begin{array}{lll} & \text { CONC. ORIG. PRES. ORIGINAL PRESENT } \\ \text { SYSTEM MAT. FLUID PCT. PH PH RES.ALK. PES.ALK. APPEAR }\end{array}$

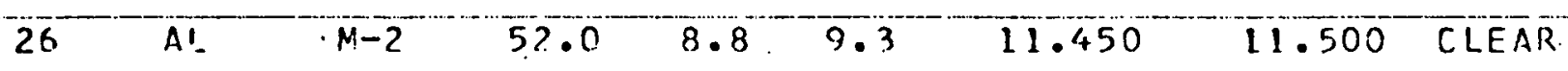

$27 \quad A L \quad M-1 \quad 52.0 \quad 9.4 \quad 9.3 \quad 9.900 \quad 9.900$ YELLOW

28 AL $\quad H-W \quad 100.0 \quad 8.2 \quad 8.5$ LT 0.100 LT 0.100 6LEAR

29 STL G-0 $59.8-5.5 \quad 6.5$ LT 0.100 LT 0.100 YELLOW

$30 \quad S T L \quad T-1 \quad 51.1 \quad 9.6 \quad 10.2 \quad 6.100 \quad 6.050 \quad R U S T$

$3 i$ STL P-2 $52.0 \quad 9.8 \quad 9.9 \quad 6.250 \quad 6.150$ YELLOW

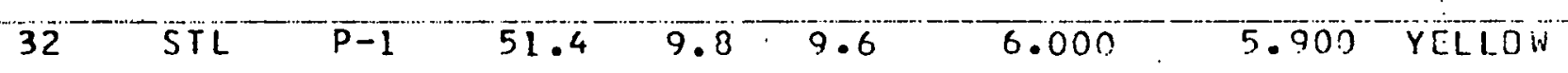

$33 \quad S T L \quad M-4 \quad 51.9 \quad 9.4 \quad 9.3 \quad 6.650 \quad 6.650 \quad$ TURBID

$\begin{array}{llllllll}34 & \text { STL } & M-3 & 51.9 & 9.5 & 9.2 & 6.650 & 6.600 \text { YELI.OW }\end{array}$

35 STL M-2 $52.5 \quad 0.8 \quad 8.8-11.450 \quad 11.400$ YELLOW

$36 \quad S T L \quad M-1 \quad 51.6 \quad 9.4 \quad 9.2 \quad 9.900 \quad 9.850 \quad Y E L L[W$

37 STL H-W $100.0 \quad 8.2 \quad 8.2 \quad 0.100 \quad$ LT 0.100 CLEAR

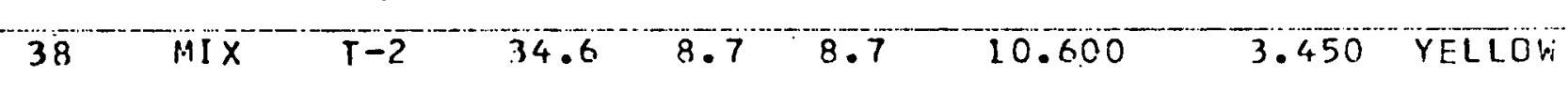




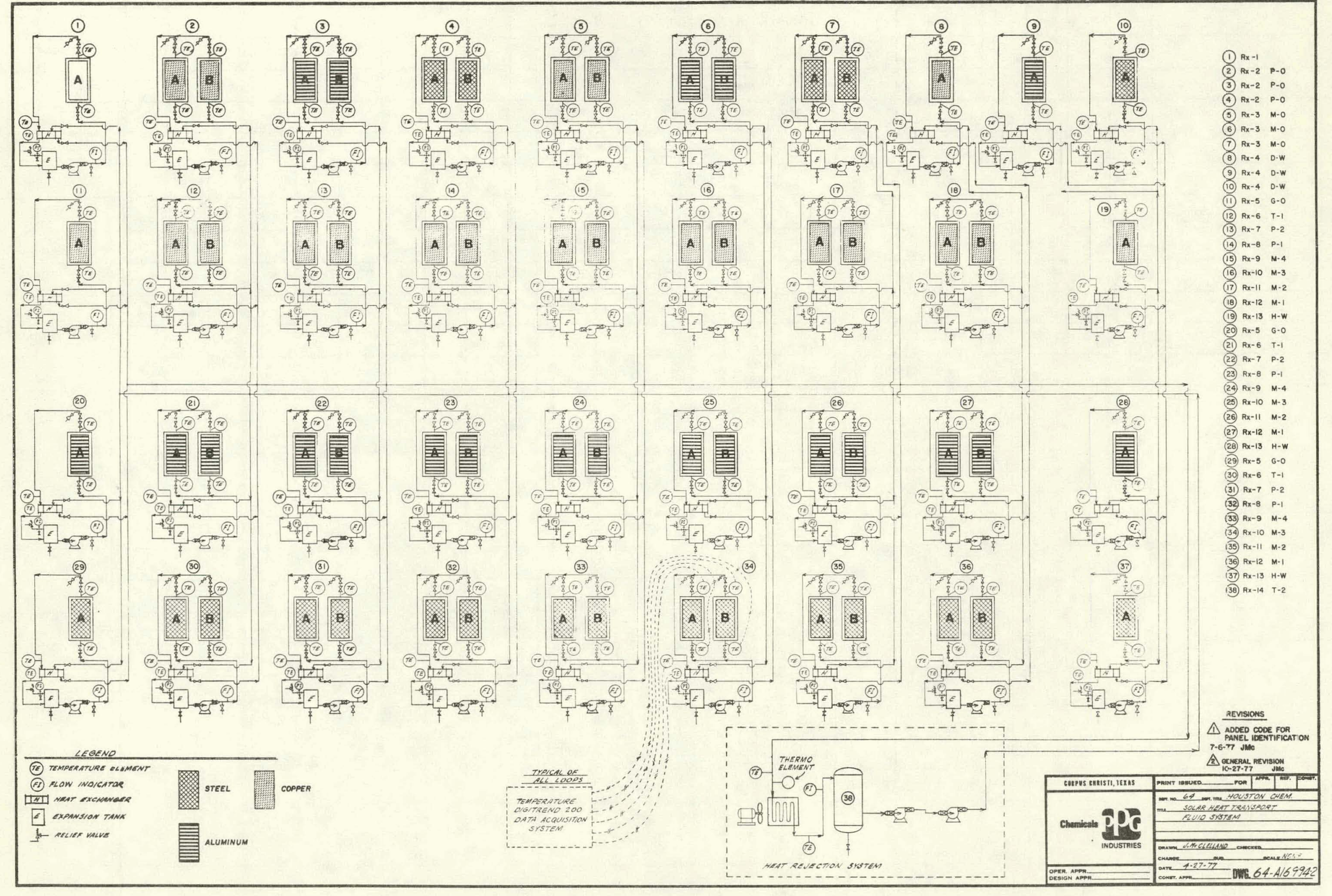


